\title{
RESEARCH
}

Open Access

\section{Benzo(a)pyrene exposure induced neuronal loss, plaque deposition, and cognitive decline in APP/PS1 mice}

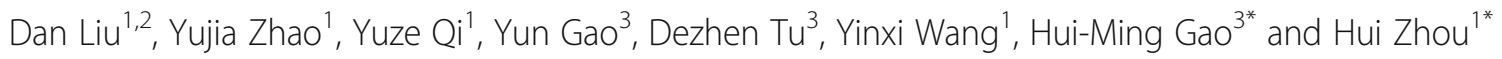

\begin{abstract}
Background: Exposure to benzo(a)pyrene (BaP) was associated with cognitive impairments and some Alzheimer's disease (AD)-like pathological changes. However, it is largely unknown whether BaP exposure participates in the disease progression of AD.

Objectives: To investigate the effect of $\mathrm{BaP}$ exposure on $\mathrm{AD}$ progression and its underlying mechanisms.

Methods: BaP or vehicle was administered to 4-month-old APPswe/PS1dE9 transgenic (APP/PS1) mice and wildtype (WT) mice for 2 months. Learning and memory ability and exploratory behaviors were evaluated 1 month after the initiation/termination of BaP exposure. AD-like pathological and biochemical alterations were examined 1 month after 2-month $\mathrm{BaP}$ exposure. Levels of soluble beta-amyloid $(A \beta)$ oligomers and the number of $A \beta$ plaques in the cortex and the hippocampus were quantified. Gene expression profiling was used to evaluate alternation of genes/pathways associated with AD onset and progression. Immunohistochemistry and Western blot were used to demonstrate neuronal loss and neuroinflammation in the cortex and the hippocampus. Treatment of primary neuron-glia cultures with aged $A \beta$ (a mixture of monomers, oligomers, and fibrils) and/or BaP was used to investigate mechanisms by which BaP enhanced $A \beta$-induced neurodegeneration.
\end{abstract}

Results: BaP exposure induced progressive decline in spatial learning/memory and exploratory behaviors in APP/PS1 mice and WT mice, and APP/PS1 mice showed severer behavioral deficits than WT mice. Moreover, BaP exposure promoted neuronal loss, A $\beta$ burden and A $\beta$ plaque formation in APP/PS1 mice, but not in WT mice. Gene expression profiling showed most robust alteration in genes and pathways related to inflammation and immunoregulatory process, A $\beta$ secretion and degradation, and synaptic formation in WT and APP/PS1 mice after BaP exposure. Consistently, the cortex and the hippocampus of WT and APP/PS1 mice displayed activation of microglia and astroglia and upregulation of inducible nitric oxide synthase (iNOS), glial fibrillary acidic protein (GFAP), and NADPH oxidase (three widely used neuroinflammatory markers) after BaP exposure. Furthermore, BaP exposure aggravated neurodegeneration induced by aged A $\beta$ peptide in primary neuron-glia cultures through enhancing NADPH oxidase-derived oxidative stress.

(Continued on next page)

\footnotetext{
* Correspondence: gaohm@nju.edu.cn; hardhui@126.com

${ }^{3}$ MOE Key Laboratory of Model Animal for Disease Study, Model Animal

Research Center, Institute for Brain Sciences, Nanjing University, 12 Xuefu Road, Nanjing 210061, Jiangsu Province, China

'Department of Occupational and Environmental Health Sciences, Peking University, Beijing 100191, China

Full list of author information is available at the end of the article
}

(C) The Author(s). 2020 Open Access This article is licensed under a Creative Commons Attribution 4.0 International License, which permits use, sharing, adaptation, distribution and reproduction in any medium or format, as long as you give appropriate credit to the original author(s) and the source, provide a link to the Creative Commons licence, and indicate if changes were made. The images or other third party material in this article are included in the article's Creative Commons licence, unless indicated otherwise in a credit line to the material. If material is not included in the article's Creative Commons licence and your intended use is not permitted by statutory regulation or exceeds the permitted use, you will need to obtain permission directly from the copyright holder. To view a copy of this licence, visit http://creativecommons.org/licenses/by/4.0/. The Creative Commons Public Domain Dedication waiver (http://creativecommons.org/publicdomain/zero/1.0/) applies to the data made available in this article, unless otherwise stated in a credit line to the data. 
(Continued from previous page)

Conclusion: Our study showed that chronic exposure to environmental pollutant BaP induced, accelerated, and exacerbated the progression of AD, in which elevated neuroinflammation and NADPH oxidase-derived oxidative insults were key pathogenic events.

Keywords: Benzo(a)pyrene, Alzheimer's disease, Cognition, Amyloid, Neuroinflammation

\section{Background}

Alzheimer's disease (AD) is the most common neurodegenerative disease with progressive loss of memory and other cognitive functions $[1,2]$. However, the etiology of AD remains largely unknown. Environmental toxins have been implicated in $\mathrm{AD}$ causation [3, 4]. Of special interest, air pollutants have been reported to be associated with acceleration of AD-like pathological changes such as beta-amyloid 42 (A 342$)$ accumulation and microglia activation [5].

Benzo(a)pyrene $(\mathrm{BaP})$, the most typical polycyclic aromatic hydrocarbons (PAHs), is a common environmental pollutant derived from incomplete combustion of organic materials, especially petroleum-based fuels and coal; BaP widely exists in ambient air, cigarette smoke, and grilled foods $[6,7]$. Because of its high lipophilicity, $\mathrm{BaP}$ and its metabolites can across the blood-brainbarrier and deposit in the brain, thus potentially causing neurotoxicity [5, 8]. Emerging evidence has indicated that $\mathrm{BaP}$ exposure might be involved in the pathogenesis process of AD. Epidemiological studies have shown that $\mathrm{BaP}$ exposure is associated with learning and memory deficits in healthy adults and coke oven workers, which may be due to neurotransmitter alteration $[9,10]$. Experimental studies have also shown that $\mathrm{BaP}$ exposure in animals induces some AD-like behavior/pathological changes, such as deficits in short-term memory in C57BL/6 J mice [11], accumulation of $A \beta 42$ and neurodegeneration in adult Zebrafish [12], A $\beta$-related mRNA levels change [13], or tau hyperphosphorylation in SD rats [14].

It is important to investigate whether $\mathrm{BaP}$ exposure participates in the disease progression of $\mathrm{AD}$, especially neurodegeneration in the cortex and the hippocampus (two major brain regions affected most in $\mathrm{AD}$ ), the fundamental feature of AD. In the present study, we provided the experimental evidence that chronic exposure to environmental pollutant BaP induced, accelerated, and exacerbated the progression of $\mathrm{AD}$ in both wildtype (WT) mice and APPswe/PSEN1 ${ }^{\triangle E 9}$ transgenic (APP/PS1) mice. Here, APP/PS1 mice, as an early-onset AD mouse model [15], was used to elucidate gene-environment interaction, namely genetic predisposition (mutant APP/PS1 genes) and chronic exposure to environmental pollutant BaP. Primary neuron-glia cultures were treated with $\mathrm{BaP}$ and/or aged $A \beta$ peptide (a mixture of monomer, oligomers, and fibrils) to investigate mechanisms of aggravation of $A \beta$ induced neurodegeneration by $\mathrm{BaP}$ exposure.

\section{Materials and methods}

\section{Animals and treatments}

The APPswe/PSEN1 ${ }^{\triangle \mathrm{E} 9}$ (also called $\mathrm{APP}^{\mathrm{K} 670 \mathrm{~N}, \mathrm{M} 671 \mathrm{~L}}$ / $\mathrm{PSEN}^{\triangle \mathrm{E} 9}$ or $\mathrm{APP}^{\mathrm{K} 595 \mathrm{~N}, \mathrm{M} 596 \mathrm{~L} / \mathrm{PSEN} 1^{\triangle \mathrm{E} 9} \text { ) transgenic }}$ (APP/PS1) mice and their wildtype (WT) littermates were obtained from Model Animal Research Center of Nanjing University. All housing and breeding of the animals were performed in strict accordance with the guidelines of the Animal Care and Committee of Nanjing University Animal Center.

The in vivo experiment was carried out as indicated by the scheme (Fig. 1). Four-month-old APP/PS1 and WT male mice were randomly divided into four groups (WT-vehicle; WT-BaP; APP/PS1-vehicle; APP/PS1-BaP; $n=10$ each group). BaP was prepared and diluted in corn oil (Sigma, US). In order to study effects of environmental pollutant $\mathrm{BaP}$ on $\mathrm{AD}$ development, we chose a chronic dosing paradigm (daily intraperitoneal injection for 2 months) and a relatively low dose of $\mathrm{BaP}(1 \mathrm{mg} / \mathrm{kg} /$ bw/day). The dose was chosen based on the environmental/occupational exposure dosage and previous studies $[11,13,14]$. Vehicle groups were received with equal volume of corn oil $(50 \mu \mathrm{l})$. As for dosing duration and timing of behavior tests and pathological/biochemical examination, we evaluated early onset of cognitive decline of $\mathrm{AD}$ after $\mathrm{BaP}$ exposure for 1 month (at the age of 5 months) and examined exacerbation of cognitive decline and AD-like pathological/biochemical features of $\mathrm{AD}$ at 1 month after $\mathrm{BaP}$ exposure for 2 months (at the age of 7 months). Two-month dosing of $\mathrm{BaP}$ and 1month "recovery" time are for better balancing detection of reliable behavior impairment in 7-month-old APP/ PS1 mice with possible general toxicity of $\mathrm{BaP}$ to the mice and repeated stress from long-time daily dosing procedure before behavior tests. All behavior tests and the result analysis were performed in a double-blinded manner.

\section{Morris water maze}

To investigate spatial learning and working memory abilities, mice were tested in the Morris water maze [16]. The Morris water maze consisted of a large circular plastic pool (diameter $120 \mathrm{~cm}$ ), which was divided into four quadrants. A circular platform (diameter $10 \mathrm{~cm}$ ) was located $1 \mathrm{~cm}$ below the surface of the opaque water, and the water temperature was kept at $22^{\circ} \mathrm{C}$. Four 


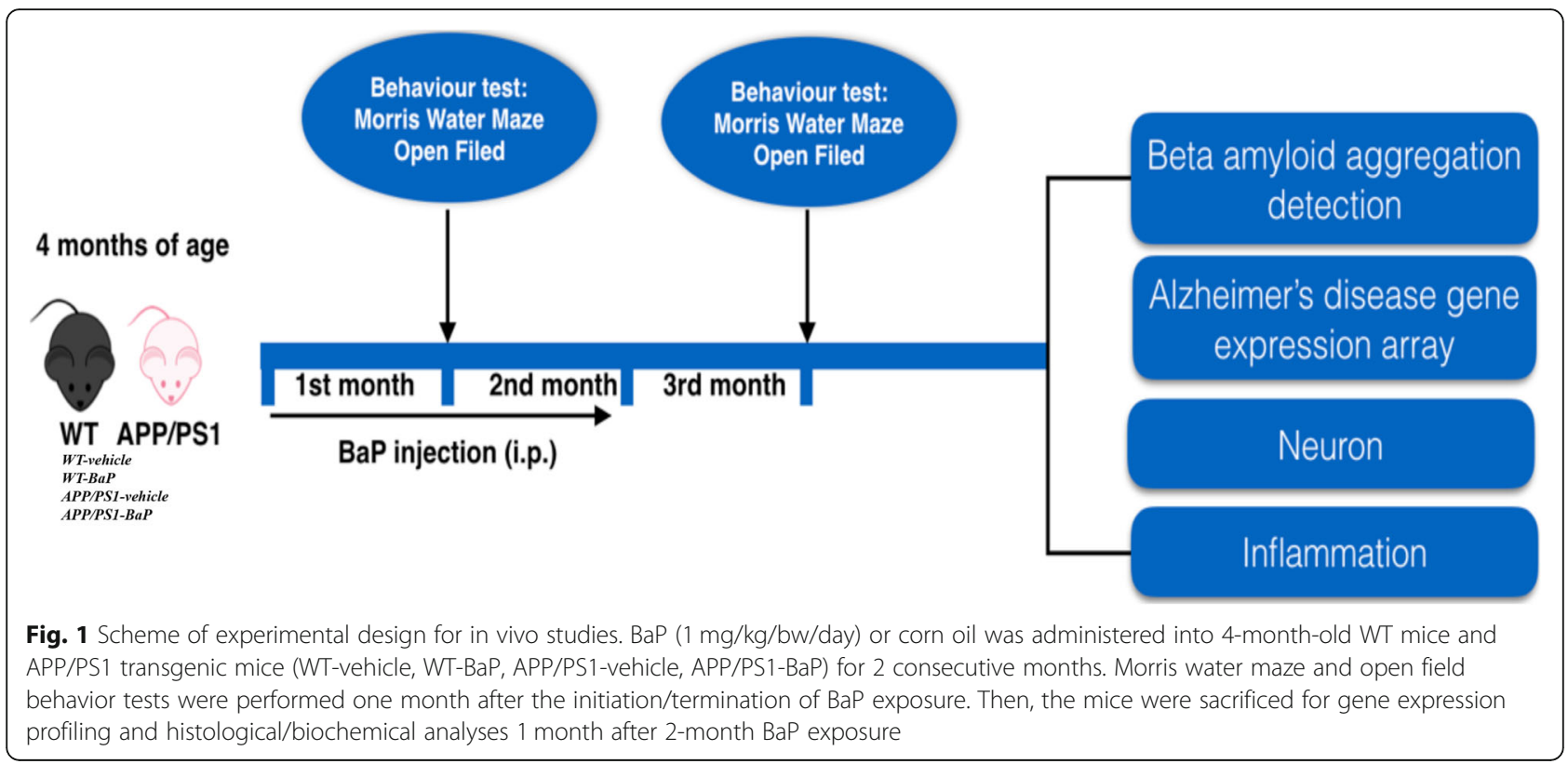

geometric images, namely a circle, square, triangle, and irregular shape with different colors were stick on the pool wall as visual spatial cues. At the acquisition phase, all mice were trained four trails per day for 5 consecutive days with the submerged platform in a fixed position. For each training trial, the mouse was given $60 \mathrm{~s}$ to find the platform. Any mouse that did not reach the platform within $60 \mathrm{~s}$ was led to the platform by the experimenter and allowed the mouse to stay on the platform for $10 \mathrm{~s}$. After $24 \mathrm{~h}$ from the last training trial, the mice were given a 60 -s probe trial without the platform in the pool. Swimming activity of each mouse was tracked via a camera linked to a computer monitoring system. All the parameters were calculated by ANYmaze software.

\section{Open field test}

The open field test measures exploratory behaviors and anxiety-related behaviors. The open field box consisted of four-square blue arenas, $40.5 \mathrm{~cm} \times 40.5$ $\mathrm{cm} \times 35.5 \mathrm{~cm}$. The center area was scored as $20 \mathrm{~cm} \times$ $20 \mathrm{~cm}$ area in the center of the open field. The mice were habituated to the behavioral room for $30 \mathrm{~min}$ prior to experimental sessions. During the test, the mouse was placed in the center of an arena and left to explore the environment freely for $20 \mathrm{~min}$. Between trials, the arena was cleaned with $70 \%$ ethanol and $\mathrm{ddH}_{2} \mathrm{O}$. All the activities of each mouse were tracked via a camera linked to a computer monitoring system. Average speed, distance traveled, central zone entries, and time spend in the central area were calculated by ANY-maze software.

\section{Brain tissue preparation}

After behavior tests conducted one month after 2month BaP exposure, the mice were anesthetized using $5 \%$ chloral hydrate and perfused transcardially with $0.9 \%$ saline; then, brains were harvested. To conduct immunohistochemistry and double-label immunofluorescence, mouse brains were fixed in $4 \%(\mathrm{w} / \mathrm{v})$ paraformaldehyde (PFA) and then cryopreserved in $30 \%(\mathrm{w} / \mathrm{v})$ sucrose/ phosphate buffer saline (PBS), and stored at $4{ }^{\circ} \mathrm{C}$. The brains were serially sectioned at $10 \mu \mathrm{m}$ in the coronal plane using Leica VT1200S Fully Automated Vibrating Blade Microtome, and sections were stored in PBS. For biochemical assay and gene array, brain regions were dissected and immediately stored at the $-80^{\circ} \mathrm{C}$. While proteins extracted from the cerebral cortex and the hippocampus were used for Western blot analysis, the total RNA isolated from cortical tissues was used for gene expression profiling.

\section{Immunohistochemistry, immunocytochemistry, and cell counting}

Immunostaining was performed as previously described $[17,18]$. Briefly, PFA-fixed cell cultures or brain sections containing the cerebral cortex and the hippocampus were treated with $3 \%$ hydrogen peroxide for $10 \mathrm{~min}$ followed by three washes with PBS and incubated with blocking solution containing $4 \%$ goat serum, $0.4 \%$ Triton $\mathrm{X}-100$, and $1 \%$ bovine serum albumin (BSA). Brain sections were then incubated overnight at $4{ }^{\circ} \mathrm{C}$ with primary antibodies. Human $\mathrm{A} \beta$ were detected with $6 \mathrm{E} 10$ (1:500, BioLegend, USA, CAT: 803002) antibody. Neurons were stained with an antibody specific for NeuN (neuron-specific nuclear-binding protein; a neuron-specific marker) 
(1:200, Millipore, USA, CAT: MAB377) or tyrosine hydroxylase (TH, a marker of dopaminergic [DA] neurons) (1:1000, Millipore, MA, CAT: AB152). Microglia and astrocytes were detected with anti-Ibal (ionized calciumbinding adaptor molecule 1; a microglia marker) (1:500, Wako, Japan, CAT: 019-19741) and anti-GFAP (glial fibrillary acidic protein, as an astroglia marker) (1:800, Millipore, USA, CAT: MAB360) antibody, respectively. Brain sections were incubated with biotinylated antirabbit (1:500, Vector Laboratories, USA, CAT: BA-1000) or anti-mouse IgG (1:500, Vector Laboratories, USA, CAT: BA-2000) antibody for $1 \mathrm{~h}$ followed by incubation with avidin-biotin complex reagents (Vector Laboratories, USA) for $1 \mathrm{~h}$, and color was developed with 3,3'-diaminobenzidine. Digital images of brain sections were acquired on an Olympus DP72 microscope. Digital images of cultured cells were recorded with a CCD (charge-coupled device) camera.

The optical density of NeuN and GFAP immunoreactivity was measured and analyzed by using Image J software, and a mean value was then deduced by averaging the density of a series of 12 sections that covered the entire cortex/hippocampus. Results were indicated as percentage of WT-vehicle group. The number of Iba- $1^{+}$cells from a series of 12 brain sections that covered the entire cortex/ hippocampus was counted by two investigators individually in a double-blind manner. For visual enumeration of the immunostained cells, images from ten areas per well were randomly taken and the TH-IR neurons were counted. For each experiment, three to four wells per treatment condition were used and results from three to four independent experiments were obtained.

\section{Thioflavin T staining}

To detect $\mathrm{A} \beta$ plaques, brain sections containing the cortex and the hippocampus mounted onto glass slides were rinsed in PBS three times and incubated in the humidity chamber for $5 \mathrm{~min}$ with the solution of $0.5 \%$ thioflavin T (Sigma-Aldrich, USA, CAT: T3516) solution in $0.1 \mathrm{~N} \mathrm{HCl}$. Brain sections were then briefly rinsed in PBS and $\mathrm{ddH}_{2} \mathrm{O}$ and cover-slipped with aqueous mounting media. Thioflavin T-stained plaques were viewed with Olympus BX53 semi-motorized fluorescence microscope (excitation wavelength, $488 \mathrm{~nm}$ ).

\section{Western blot analysis}

The cortex and the hippocampus were gently homogenized in cold RIPA buffer (Radioimmunoprecipitation assay buffer; $50 \mathrm{mM}$ Tris-HCl, pH 8.0, $5 \mathrm{mM}$ EDTA, 150 $\mathrm{mM} \mathrm{NaCl}, 1 \%$ Triton X-100, $0.5 \%$ sodium deoxycholate, $0.1 \%$ SDS, and protease inhibitor cocktail) on ice, centrifuged at $175,000 \times g$ for $1 \mathrm{~h}$ at $4{ }^{\circ} \mathrm{C}$ and the soluble supernatant was collected. The protein concentration was determined with Pierce BCA assay kit (ThermoFisher,
USA). Equal amounts of total protein ( $50 \mu \mathrm{g}$ per lane) were separated on $4 \sim 12 \%$ Bis-Tris-polyacrylamide electrophoresis gel and transferred to polyvinylidene difluoride membranes. Membranes were blocked with 5\% nonfat milk and incubated with the following primary antibodies overnight at $4{ }^{\circ} \mathrm{C}$ : anti-NeuN (1:1000, Millipore, USA, CAT: MAB377), anti-A $\beta$ (6E10; 1:1000, BioLegend, USA, CAT: 803002), anti-GFAP (1:1000, Millipore, USA, CAT: MAB360), anti-gp91 (1:1000, BD, USA, CAT: 611414), anti-iNOS (1:1000, Santa Cruz, USA, CAT: sc$7271)$, and anti- $\beta$-actin (1:1000, Cell Signaling Technology, USA, CAT: 8457). The membrane was then incubated with horseradish peroxidase-linked anti-rabbit (1:2000, Cell Signaling Technology, USA, CAT: 7074) or antimouse IgG (1:2000, Cell Signaling Technology, USA, CAT: 7076) for $1 \mathrm{~h}$. The blots were detected with enhanced chemiluminescence (ECL) reagent. Images were analyzed by Image J software.

\section{Alzheimer's disease gene expression profile array}

The gene expression profile related to Alzheimer's disease was quantified using Alzheimer's disease gene expression profile array (GeneCopoeia, USA). The gene primer pairs were used for the mRNA expression. In short, the total RNA was isolated from cortical tissues using Trizol reagent following the manufacturer's direction. An aliquot of RNA $(1 \mu \mathrm{g})$ was reverse-transcribed into cDNA using the First Strand cDNA synthesis kit (GeneCopoeia, USA). The final cDNA product was used for array using SYBR-Green-based real-time PCR according to the manufactures' protocol. The amplification was run in the CFX Connect Real-Time PCR Detection system (Bio-Rad, USA). A dissociation curve was used to verify that majority of fluorescence detected was attributed to the labeling of specific PCR products. Relative gene mRNA expression ratios between groups were calculated using the $\Delta \Delta \mathrm{Ct}$ formulation. All the data were normalized to that of glyceraldehyde-3-phosphate dehydrogenase (GAPDH) in the same sample.

\section{Primary neuron-glia cultures}

Sprague-Dawley (SD) rats were obtained from the Animal Center of Peking University Health Science Center. Mesencephalic primary neuron-glia cultures were prepared from the ventral mesencephalon of embryonic day $14 \pm 0.5 \mathrm{SD}$ rats as described before [18]. Briefly, neuron-glia cultures were maintained in MEM (Minimum Essential Medium) supplemented with 10\% heat-inactivated fetal bovine serum (FBS) and 10\% heatinactivated horse serum (HS), $1 \mathrm{~g} / \mathrm{l}$ glucose, $2 \mathrm{mM} \mathrm{L-glu-}$ tamine, $1 \mathrm{mM}$ sodium pyruvate, and $0.1 \mathrm{mM}$ nonessential amino acids. Seven-day-old cultures were treated with vehicle or desirable reagents in the treatment medium (MEM containing 2\% FBS, 2\% HS, 2 mM L- 
glutamine and $1 \mathrm{mM}$ sodium pyruvate). At the time of treatment, the neuron-glia cultures were made up of $10 \%$ microglia, $50 \%$ astrocytes, and $40 \%$ neurons of which $3-4 \%$ were $\mathrm{TH}$-immunoreactive (IR) neurons.

\section{Preparation of aged $A \beta_{1-42}$ peptide}

Synthesized human $A \beta_{1-42}$ peptide (China peptides, China) was purchased to prepare aged $A \beta$ solution as described before [19]. The $A \beta$ peptide was equilibrated to room temperature for $30 \mathrm{~min}$ before dissolved in 100\% 1,1,1,3,3,3-hexafluoro-2-propanol (HFIP, Sigma) to $1 \mathrm{mM}$. After being incubated for $2 \mathrm{~h}$ at room temperature, the peptide was dried under vacuum to form peptide films. The peptide film was dissolved in cold sterile phosphate butter saline (PBS) to $100 \mu \mathrm{M}$, and after vortexed for $30 \mathrm{~s}, A \beta$ solution was incubated at $37^{\circ} \mathrm{C}$ for $24 \mathrm{~h}$ to form the aged $\mathrm{A} \beta$, which contained $A \beta$ monomer, oligomers, and fibrils.

\section{Measurement of extracellular superoxide}

The production of superoxide was determined by measuring the superoxide dismutase (SOD)-inhibitable reduction of WST-1 (water-soluble tetrazolium 1) as previously described [20]. Neuron-glia cultures grown in 96-well plates were washed and refilled with $150 \mu \mathrm{l}$ of phenol red-free treatment medium. Fifty microliters of HBSS (Hank's Balanced Salt Solution) containing vehicle or corresponding treatment reagents were then added to each well, followed by addition of $50 \mu \mathrm{l}$ of WST-1 $(1 \mathrm{mM})$ in HBSS with or without $600 \mathrm{U} / \mathrm{ml} \mathrm{SOD}$. The cultures were incubated for $30 \mathrm{~min}$ at $37^{\circ} \mathrm{C}$, and the absorbance at $450 \mathrm{~nm}$ was read with a SpectraMax Plus microplate spectrophotometer (Molecular Devices, CA).

\section{Statistical analysis}

Data were presented as the mean \pm standard error $(\mathrm{SE})$. Differences of parameters in Morris water maze and open filed were detected using repeated measures ANOVA. Statistical significance of other parameters between multiple groups was performed using one- or two-way analysis of variance (ANOVA). When ANOVA showed significant difference, least significant difference (LSD) multiple comparisons post-hoc test was performed. A value of $P<0.05$ (two-tailed) was considered statistically significant. Statistical analyses were conducted by SPSS 13.0 software (Chicago, IL, USA).

\section{Results}

\section{$\mathrm{BaP}$ exposure induced progressive cognitive decline in} WT and APP/PS1 mice

Mouse cognitive functions were evaluated by Morris water maze immediately after BaP exposure for 1 month (at the age of 5 months) and 1 month after 2-month BaP exposure (at the age of 7 months). In the place navigation test, the escape latency to the target platform during the 5-day training period for spatial learning was recorded in Fig. 2a. As an AD animal model, APP/PS1 mice exhibited a longer latency to locate the platform than WT mice. After administration of $\mathrm{BaP}$, the escape latency significantly increased in both WT and APP/PS1 mice $(F=$ 17.80, $P<0.01$ ). After training, the hidden platform was removed for the probe test. In the post-training probe test, while the swim paths of WT-Vehicle mice showed directed path-navigation in the target quadrant, the swim paths of WT-BaP mice, APP/PS1-Vehicle mice, and APP/ PS1-BaP mice appeared circuitous paths across the area of the pool without obvious preference for the target quadrant (Fig. 2b). After 1-month exposure, APP/PS1-BaP mice showed longer latency to the first entry to the target quadrant $(p<0.01)$ (Fig. 2c), less entry frequency to the target quadrant $(p<0.01)$ (Fig. 2e) and less time in the target quadrant $(p<0.01)$ than APP/PS1-Vehicle mice and WT-BaP mice in the post-training probe test (Fig. 2d). WT-BaP mice showed fewer entries to the target quadrant than WT-Vehicle mice $(p<0.01)$ (Fig. 2e). Two-month $\mathrm{BaP}$ exposure made cognitive decline more profound in both WT and APP/PS1 mice (Fig. 2). Thus, BaP induced progressive cognitive deficits in both WT and APP/PS1 mice and caused much severer cognition declines in APP/ PS1 mice than WT mice. Moreover, no difference in the swimming speed among all mouse groups (data not shown) indicated that the observed behavior deficits were authentic learning and memory decline but not a result of poor swimming capacity. Collectively, chronic BaP exposure induced, accelerated and/or exacerbated AD-like cognitive decline in WT mice and APP/PS1 mice.

\section{BaP exposure exacerbated progressive exploratory ability impairment}

The exploratory ability and anxiety-related activities were quantified by the open field test. Represented track record images during the test were shown in Fig. 3a. After exposure for 1 month, both WT-BaP and APP/ PS1-BaP mice traveled less distance (Fig. 3b), had less mobile time (Fig. 3c) and were less willing to enter the center zone. These behavior impairments further deteriorated after 2-month BaP exposure (Fig. 3d). Altogether, $\mathrm{BaP}$ exposure induced progressive exploratory behavior impairment and anxiety-related behavior. Genetic predisposition (mutant APP/PS1 genes) exacerbated such behavior deficits.

\section{BaP exposure promoted neuronal loss in APP/PS1 mice}

We evaluated the neuronal loss at one month after 2month BaP exposure in both WT and APP/PS1 mice. As shown in Fig. 4a, BaP induced remarkably neuronal loss by $26 \%$ in the cortex $(p<0.05)$ and by $44 \%$ in the 

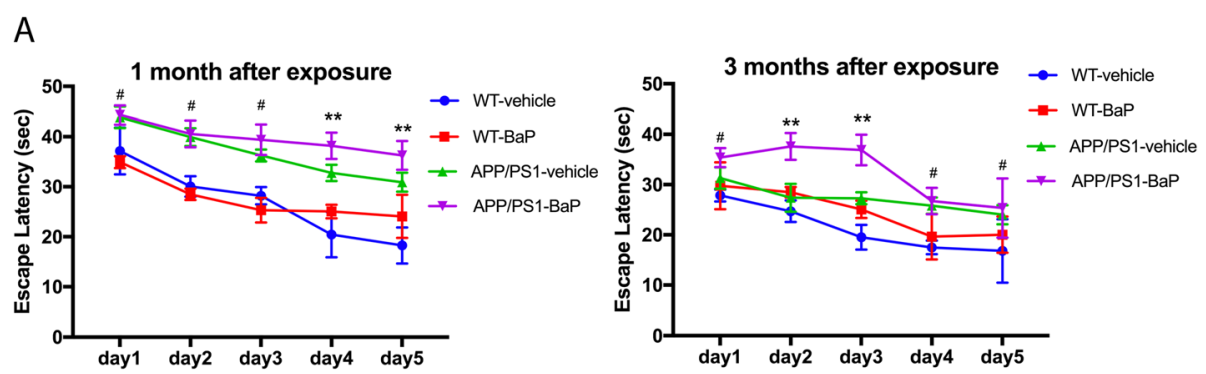

B 1 month after exposure
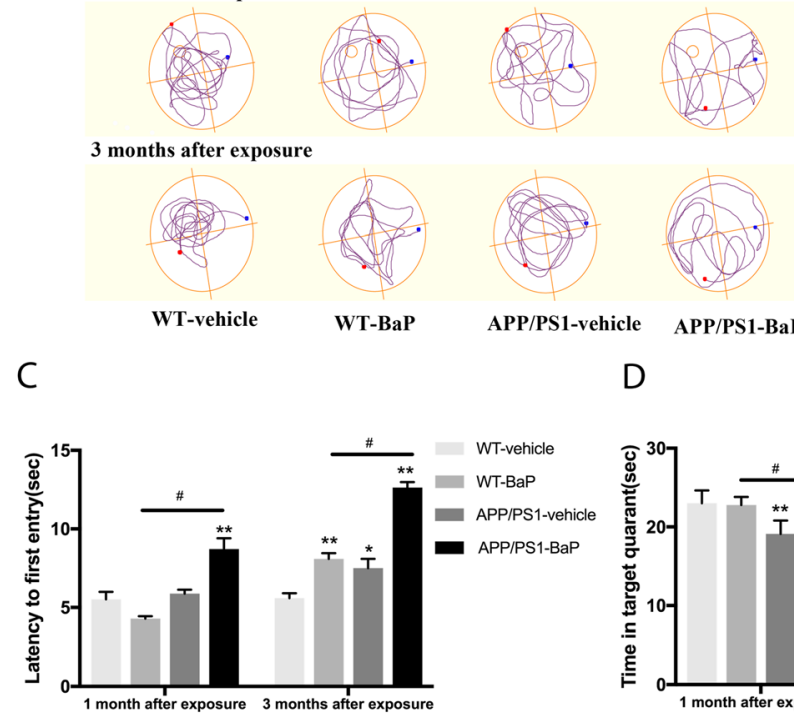

APP/PS1-BaP

D

$E$
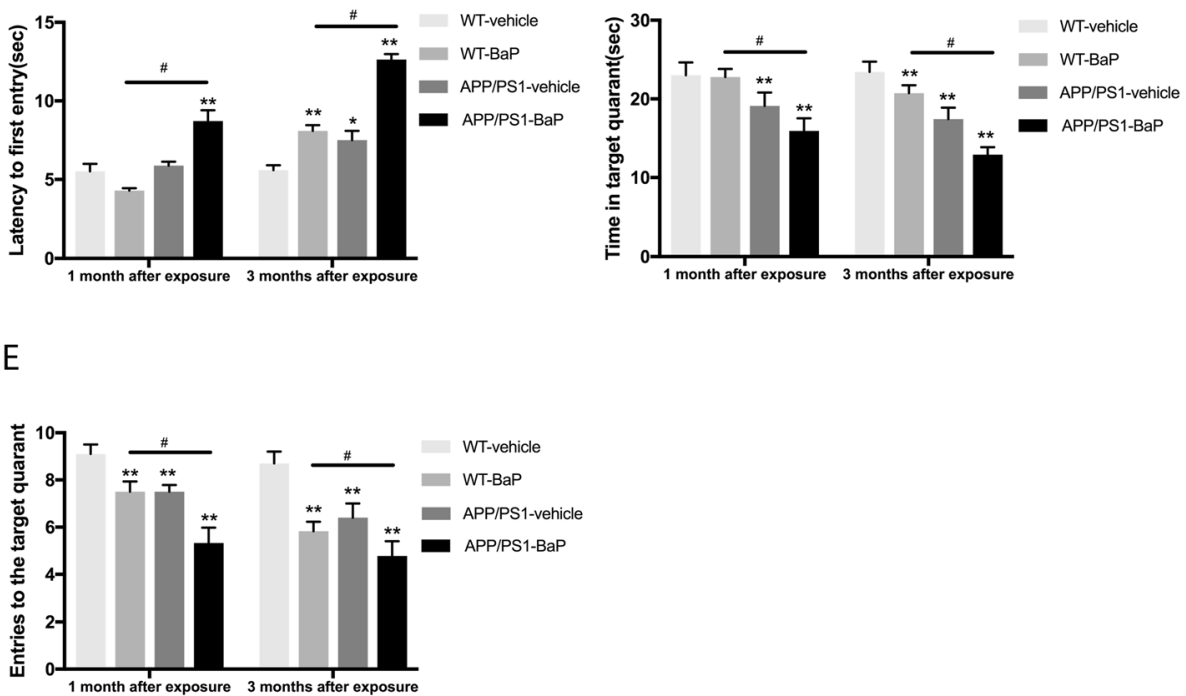

Fig. $2 \mathrm{BaP}$ exposure accelerated progressive spatial and working memory decline in the Morris water maze test. a Escape latency during 5 days training performed immediately after BaP exposure for 1 month or 1 month after 2-month BaP exposure. b Representative path maps of each group in the probe trail. $\mathbf{c}$ Latency to the first entry to the target quadrant in the probe trail. $\mathbf{d}$ Time spent in the target quadrant in the probe trail. e Entries to the platform quadrant in the probe trail. $N=10 /$ group. Data are mean $\pm S E M,{ }^{*} P<0.05$ and ${ }^{*} P<0.01$ compared with WTVehicle control; ${ }^{\# P}<0.05$ compared with WT-BaP group

hippocampus $(p<0.05)$ in APP/PS1 mice. However, no significant neuron loss was shown in WT groups. Significant reduction in the level of NeuN protein in the cortex/ hippocampus in APP/PS1 mice after BaP exposure but not in WT groups (Fig. 4b) also supported that genetic predisposition (mutant APP/PS1 genes) and chronic exposure to environmental pollutant $\mathrm{BaP}$ together induced synergistic neuronal loss.

\section{BaP exposure exacerbated $A \beta$ burden and $A \beta$ deposition in APP/PS1 mice}

Since APP/PS1 mice were considered as the ideal model for analyzing amyloidosis in the pathogenesis of $\mathrm{AD}$, effects of $\mathrm{BaP}$ exposure on amyloidosis were elucidated by immunohistochemistry, Thioflavin-T (ThioT) stain, and Western blot assays. Immunohistochemistry analysis of $\mathrm{A} \beta$ deposition showed that $\mathrm{BaP}$ exposure significantly 


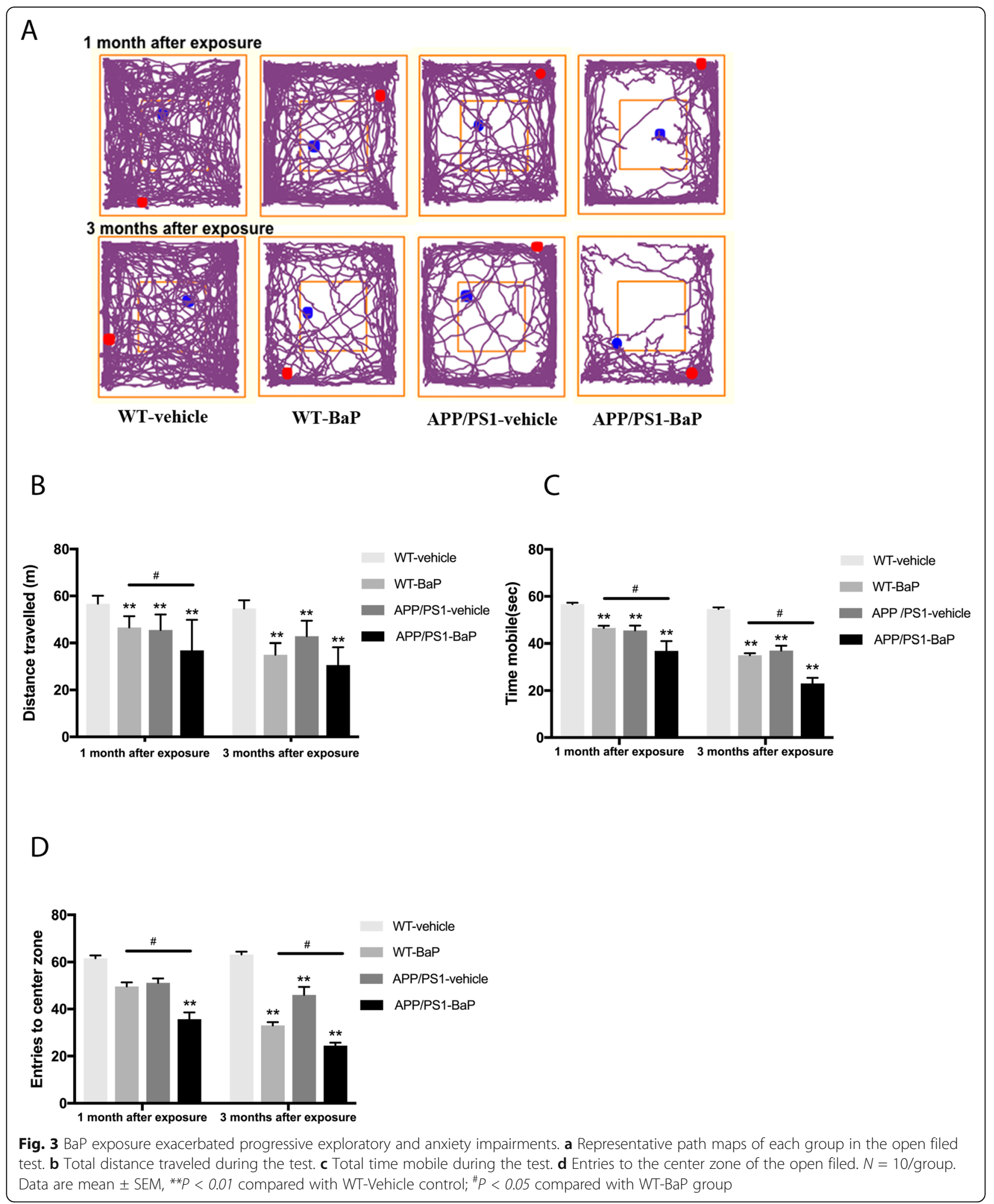

increased plaque burden by more than 2 -fold in both cortex and hippocampus $(p<0.05)$ in APP/PS1 mice (Fig. 5a). The ThioT-positive $\mathrm{A} \beta$ compact plaques increased by $53 \%$ in the cortex $(p<0.05)$ and by $44 \%$ in the hippocampus $(p<0.05)$ (Fig. 5b). These findings indicated that $\mathrm{BaP}$ exposure exacerbated a key pathological 
A

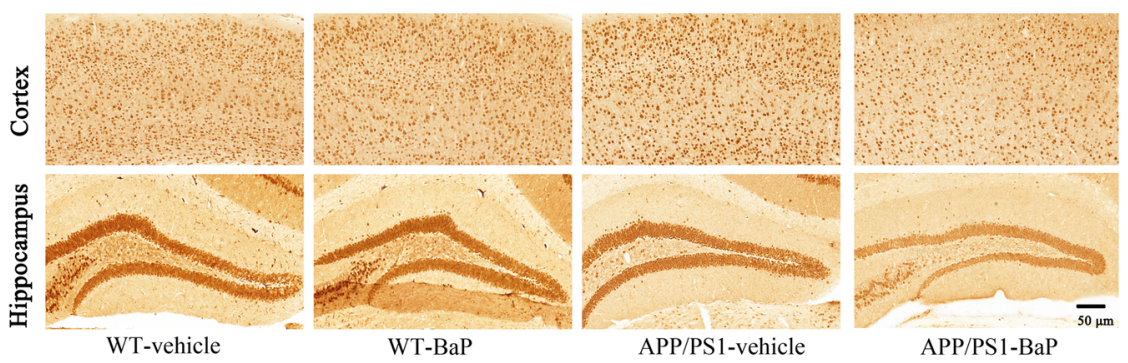

NeuN immunoreactivity

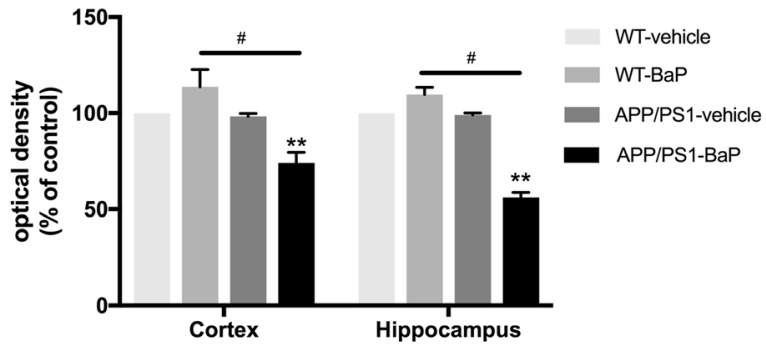

B
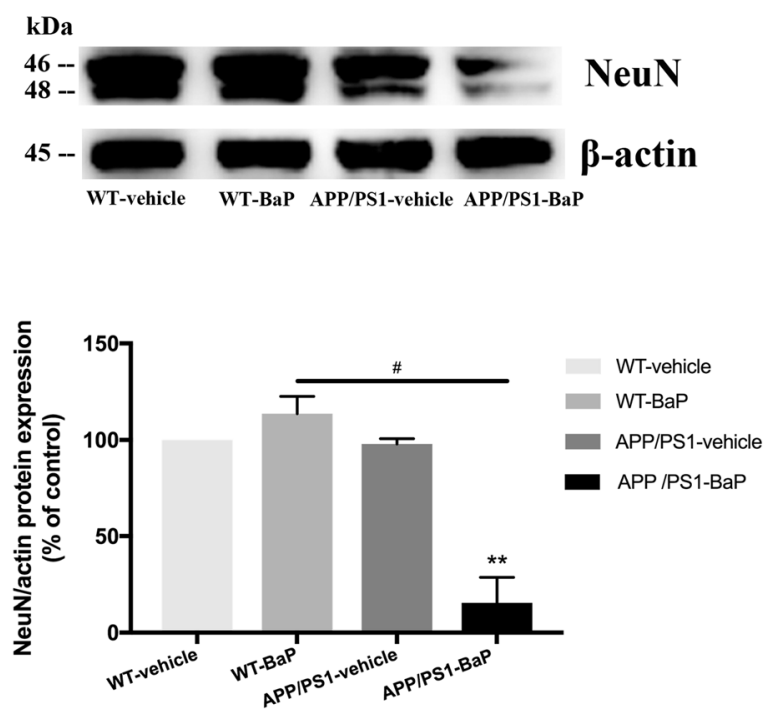

Fig. $4 \mathrm{BaP}$ exposure induced neuronal loss only in APP/PS1 mice. a Representative images of immunohistochemical staining of NeuN in the cortex and the hippocampus. The quantification results of NeuN immunoreactivity are expressed as a percentage of the corresponding WTVehicle control. $\mathbf{b}$ Levels of NeuN protein in the cortex and the hippocampus were detected by Western blot. $\beta$-actin was used to monitor loading errors. Data are expressed as a percentage of the WT-Vehicle control. Data are mean \pm SEM of 3-4 mice in each group. Significance was determined by two-way ANOVA followed by LSD multiple comparisons post-hoc test. ${ }^{*} P<0.01$ compared with WT-Vehicle control, ${ }^{\#} P<0.05$ compared with WT-BaP group

feature of $\mathrm{AD}$, formation of $\mathrm{A} \beta$ plaques and $\mathrm{A} \beta$ fibrils. Because more and more studies have documented a pivotal role of $A \beta$ oligomers in the pathogenesis of $A D$, we used the RIPA buffer to extract soluble $A \beta$ monomers and oligomers. Western blot results showed a dramatic increase in $A \beta$ oligomers in the cortex/hippocampus of APP/PS1 mice after BaP exposure (Fig. 5c). The level of $\mathrm{A} \beta$ monomer and amyloid precursor protein (APP, a 770 amino acid protein with a molecular mass of $\sim 100$ $\mathrm{kDa}$, which can be detected by $6 \mathrm{E} 10$ antibody) also 
A
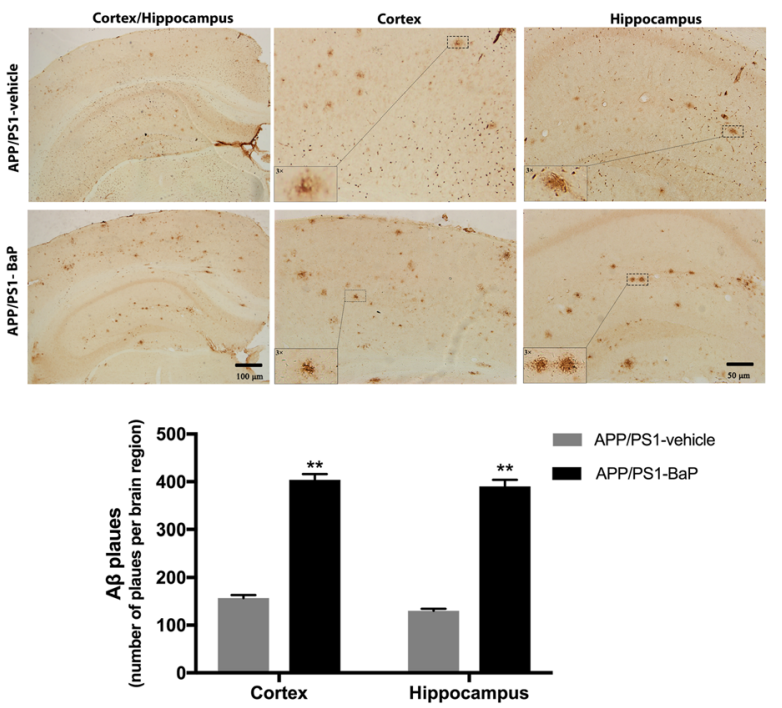

B
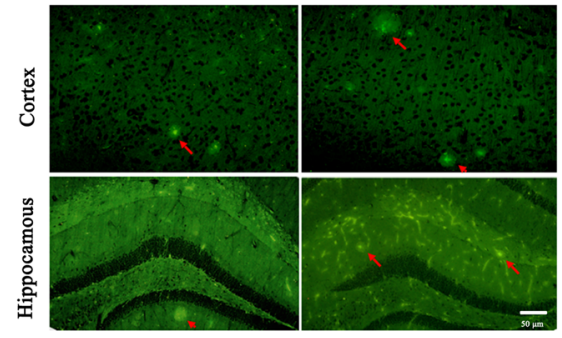

APP/PS1-vehicle

APP/PS1-BaP

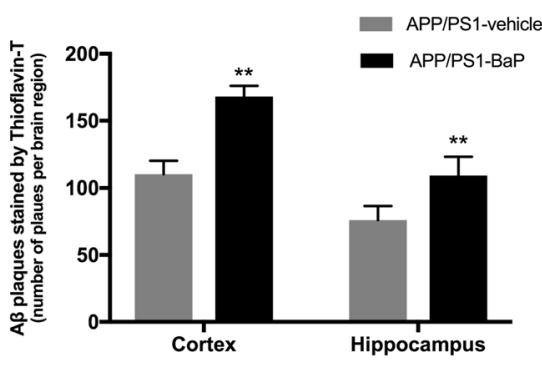

C
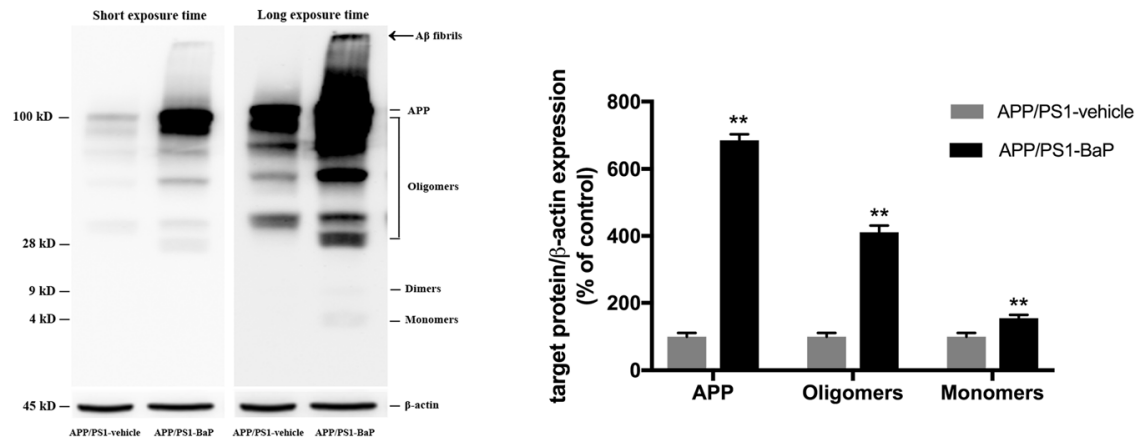

Fig. 5 BaP exposure exacerbated A $\beta$ burden and plaque formation in APP/PS1 mice. a Representative images of immunohistochemical staining of human $A \beta$ using 6 E10 antibody in the cortex and the hippocampus of APP/PS1 mice. Total number of A $\beta$ plaques was counted. $\mathbf{b}$ Thioflavin-T staining showed A $\beta$ plaques in the cortex and the hippocampus of APP/PS1 mice. Number of A $\beta$ plaques was counted. $\mathbf{c}$ Levels of RIPA soluble $A \beta$ species and APP were detected by Western blot using 6 E10 antibody for human A $3 / A P P$. $\beta$-actin was used to monitor loading errors. The ratio of densitometry values of A $\beta$ monomer (measured in the image with long exposure time), oligomers, and APP (measured in the image with short exposure time) was normalized to $\beta$-actin. Data are expressed as a percentage of APP/PS1-Vehicle control and are mean \pm SEM of 3-4 mice in each treatment group. Significance was determined by $t$ test. ${ }^{* *} P<0.01$ compared with APP/PS1-Vehicle. Arrow indicates A $\beta$ fibrils stuck in the loading well of the SDS-PAGE gel and then transferred to the PVDF membrane

significantly increased (Fig. 5c). Collectively, these results indicated $\mathrm{BaP}$ exposure exacerbated accumulation of both soluble $A \beta$ monomer and oligomers and insoluble $\mathrm{A} \beta$ fibrils in the cortex and the hippocampus of APP/ PS1 mice.
BaP exposure altered AD-related gene expression profiles In this study, the mouse Alzheimer's Disease $\mathrm{RT}^{2}$ Profiler PCR Array was used to analyze the BaP-induced alternations of gene expression profiles in the cortex of both WT and APP/PS1 mice. Among 101 tested genes 
(Supplemental table 1), the ones with differential expression in WT-BaP, APP/PS1-Vehicle, and APP/PS1-BaP mice compared with WT-Vehicle (Table 1) were linked to $A \beta$ generation, clearance and degradation, neuroinflammation, and neuronal damages. In general, the BaPinduced alternation of gene expression profiles was more profound in APP/PS1 mice than that in WT mice. Although no clear amyloidosis was observed in WT-BaP mice (data not shown), gene expression profiles showed significant changes in multiple genes related to $A \beta$ generation, clearance, and degradation in WT mice upon $\mathrm{BaP}$ exposure. Notably, gene expression changes and resultant functional alterations of the corresponding proteins in WT-BaP mice could be partial reason for neurobehavioral deficits in WT-BaP mice and could represent the initial phase of the incipient AD. Genetic predisposition (mutant APP/PS1 genes) facilitated the BaPinduced pathogenic progress.

Pathways and functional systems of the differentially modulated genes were further analyzed. Among the highlighted categories, inflammation and immunoregulatory process, $A \beta$ secretes, and degradation and synaptic formation pathways/systems emerged as the most robustly altered in $\mathrm{AD}$ progression after $\mathrm{BaP}$ exposure. As shown in Table 1, almost all the $A \beta$ secretion-related proteins tested in this study were significantly increased in APP/PS1 mice after BaP exposure but not in WT mice. For instance, in APP/PS1 mice, beta-secretase 1 (Bace1, as known as beta-site APP cleaving enzyme 1), presenilin proteins (Psen $1 / 2$ ), and aph-1 homolog b (Aph1b) were raised to 2.93-, 1.88-, and 3.20-folds respectively after $\mathrm{BaP}$ exposure. However, mild changes of these proteins in WT-BaP mice (Table 1) suggested that $\mathrm{BaP}$ facilitated abnormal A $\beta$ secretion in APP/PS1 mice, which was in concordance with accelerated/exacerbated $\mathrm{A} \beta$ burden observed in APP/PS1-BaP mice (Fig. 5c). Interestingly, $A \beta$ degradation-related proteins such as membrane metalloendopeptidase (MME), plasminogen activator (Plau), and insulin degrading enzyme (IDE) were also elevated in APP/PS1-BaP mice, but not in WT-BaP mice, which is consistent with deteriorated $A \beta$ burden in APP/PS1 mice after BaP exposure.

The gene expression profiles related to synaptic formation were also remarkably changed in BaP-treated mice. Agrin, known to be important for synaptic differentiation, formation, and/or maintenance [21-23], was significant decreased in APP/PS1 mice after BaP exposure (Table 1). Altered expression and abnormal distribution of agrin in AD brain contribute to AD pathogenesis [21]. Slc6a4, a gene encoding SERT (serotonin transporter), was significantly downregulated in APP/PS1 mice with or without BaP exposure (Table 1). The brain of AD patients show reduced SERT in both protein and mRNA, and reduced SERT is associated with depression and anxiety in $\mathrm{AD}[24,25]$. Acetylcholinesterase (AChE) was remarkably upregulated in WT and APP/PS1 mice after $\mathrm{BaP}$ exposure (Table 1). Studies have shown increased AChE activity in plasma and elevated AChE levels around amyloid plaques in AD patients [26, 27]. Interestingly, neurotropic factors BDNF (brain-derived neurotrophic factor) and GNDF (glial cell line-derived neurotrophic factor) were upregulated in WT and APP/ PS1 mice, which could be protective responses to BaPinduced neuronal damages. These findings together suggested that $\mathrm{BaP}$ exposure might induce synaptic loss/ dysfunction.

It is notable that neuroinflammatory responses were the pathway with the most robust alteration after $\mathrm{BaP}$ exposure in both WT and APP/PS1 mice. Neuroinflammatory cytokines (e.g., TNF $\alpha$, IL3, TREM2, IL1 $\beta$, and IL6) were slightly increased in WT-BaP mice, but remarkably upregulated in APP/PS1-BaP mice, which indicated persistent neuroinflammation in BaP-induced APP/PS1 mice. In addition, multiple subunits of NADP $\mathrm{H}$ oxidase including gp91, p67, p40, and $\mathrm{p} 47$ were remarkably upregulated. In particular, gp91 (the catalytic subunit of NADPH oxidase) was upregulated by 3.19folds and 5.71-folds in WT-BaP mice and APP/PS1-BaP mice, respectively (Table 1 ). Taken together, these alternation patterns of gene expression in WT and APP/PS1 mice after $\mathrm{BaP}$ exposure indicated that $\mathrm{BaP}$ could initiate AD-related pathological and biochemical pathways to precipitate in AD progression. Notably, sustained neuroinflammatory responses may play a crucial role in $\mathrm{BaP}-/ \mathrm{A} \beta$-induced AD-like phenotypes. Neuroinflammation has been believed to be the key molecular event in the initial phase of AD; We next investigated how neuroinflammation and NADPH oxidase activation affected BaP's aggravation of $A \beta$-induced $A D$ progression.

\section{BaP exposure induced neuroinflammation}

As shown in Fig. 6a and b, in comparison to vehicle controls, the number of $\mathrm{Iba}^{+}$microglia in the cortex was increased by $62.7 \%$ and $90.8 \%$ in WT-BaP mice and APP/PS1-BaP mice respectively, and microglial number in the hippocampus increased by $77.1 \%$ and $94.3 \%$ in WT-BaP mice and APP/PS1-BaP mice. Confocal doublelabel immunofluorescence also showed more prominent microglial activation in APP/PS1 mice after BaP exposure (Fig. 6c). Activated microglia in BaP-exposed mice appeared to have larger cell body and stronger staining of Iba1 (Fig. 6a, c). In addition, astroglia displayed remarkable increase in the immunoreactivity for GFAP (an astroglial marker) in both WT and APP/PS1 mice after $\mathrm{BaP}$ exposure, and APP/PS1-BaP mice exhibited higher immunoreactivity for GFAP than WT-BaP mice (Fig. 6d, e). These results indicated that $\mathrm{BaP}$ induced severer astrogliosis in APP/PS1 mice. Collectively, BaP exposure 
Table 1 The differential Alzheimer's disease gene expression profiles in WT and APP/PS1 mice after BaP exposure

\begin{tabular}{|c|c|c|c|c|c|}
\hline Category & Gene & $\begin{array}{l}\text { WT-vehicle } \\
\text { (fold change) }\end{array}$ & $\begin{array}{l}\text { WT-BaP } \\
\text { (fold change) }\end{array}$ & $\begin{array}{l}\text { APP/PS1-vehicle } \\
\text { (fold change) }\end{array}$ & $\begin{array}{l}\text { APP/PS1-BaP } \\
\text { (fold change) }\end{array}$ \\
\hline \multirow{16}{*}{$\begin{array}{l}\text { Inflammatory and } \\
\text { immunoregulatory process }\end{array}$} & Interleukin 1 alpha (II1a) & 1.00 & 0.97 & 0.90 & $1.92^{* \#}$ \\
\hline & Interleukin 1 beta (IL1ß) & 1.00 & $0.65^{* *}$ & $4.01^{* *}$ & $4.67^{* * \#}$ \\
\hline & Interleukin 3 (IL3) & 1.00 & $3.75^{*}$ & $2.82^{*}$ & $3.81^{*}$ \\
\hline & Interleukin 6 (II6) & 1.00 & 0.94 & 1.30 & $2.14^{* \#}$ \\
\hline & gp91 & 1.00 & $3.19^{*}$ & $4.88^{*}$ & $5.71^{*}$ \\
\hline & p67 & 1.00 & 1.51 & $2.75^{*}$ & $2.76^{*}$ \\
\hline & $\mathrm{p} 47$ & 1.00 & 0.99 & 1.42 & 1.36 \\
\hline & $\mathrm{p} 40$ & 1.00 & 1.17 & $1.97^{*}$ & $1.77^{*}$ \\
\hline & iNOS & 1.00 & $0.58^{*}$ & 0.75 & $1.41^{* \#}$ \\
\hline & CD36 antigen (Cd36) & 1.00 & $2.65^{* *}$ & $2.58^{* *}$ & $7.41^{* * \#}$ \\
\hline & Chemokine ligand 5 (Ccl5) & 1.00 & 1.03 & $4.19^{*}$ & $2.91^{* * \#}$ \\
\hline & Chemokine ligand 7 (Ccl7) & 1.00 & 1.25 & $2.14^{*}$ & $1.56^{*}$ \\
\hline & Tumor necrosis factor (Tnf) & 1.00 & $1.70^{*}$ & $2.61^{* *}$ & $10.19^{* * \#}$ \\
\hline & Arginase (Arg1) & 1.00 & 0.94 & 1.40 & $5.61^{* \#}$ \\
\hline & TREM2 & 1.00 & 1.06 & $1.67^{*}$ & $5.86^{* \#}$ \\
\hline & Prostaglandin-endoperoxide synthase 2 (Ptgs2) & 1.00 & $1.60^{*}$ & 0.92 & $2.89^{*}$ \\
\hline \multirow[t]{7}{*}{ Secretases } & Amyloid beta precursor protein (APP) & 1.00 & $2.51^{*}$ & $6.56^{*}$ & $8.15^{* \#}$ \\
\hline & Beta-site APP cleaving enzyme 1 (Bace1) & 1.00 & $1.24^{*}$ & $2.10^{*}$ & $2.93^{* \#}$ \\
\hline & Presenilin 1 (Psen1) & 1.00 & 0.97 & $2.07^{*}$ & $2.93^{* * \#}$ \\
\hline & Presenilin 2 (Psen2) & 1.00 & 0.93 & 1.27 & $1.88^{* \#}$ \\
\hline & Nicastrin (Ncstn) & 1.00 & 1.04 & $2.61^{* *}$ & $3.24^{* * \#}$ \\
\hline & Anterior pharynx defective 1b homolog (Aph1b) & 1.00 & $1.44^{*}$ & $2.78^{* *}$ & $3.20^{* \#}$ \\
\hline & Presenilin enhancer 2 (Pen2) & 1.00 & 1.15 & 1.11 & 1.15 \\
\hline \multirow[t]{4}{*}{ Beta-amyloid degradation } & Membrane metallo endopeptidase & 1.00 & $1.77^{*}$ & 1.32 & $4.75^{* \#}$ \\
\hline & Plasminogen activator (Plau) & 1.00 & 1.05 & $3.13^{*}$ & $3.97^{* \#}$ \\
\hline & Insulin degrading enzyme (IDE) & 1.00 & 1.04 & $2.53^{* *}$ & $3.16^{* \#}$ \\
\hline & Neprilysin (NEP) & 1.00 & $2.53^{*}$ & $0.29^{*}$ & $0.52^{* \#}$ \\
\hline \multirow[t]{8}{*}{ Synaptic formation } & Zinc transporter (SIc30a3) & 1.00 & $1.75^{* *}$ & 0.86 & $2.81^{*}$ \\
\hline & Aplipoprotein E (Apoe) & 1.00 & $2.17^{*}$ & $0.85^{*}$ & $1.49^{*}$ \\
\hline & Brain-derived neurotrophic factor (Bdnf) & 1.00 & $1.43^{* *}$ & $3.34^{* *}$ & $3.65^{* * \#}$ \\
\hline & Nerve growth factor receptor (Ngfr) & 1.00 & $1.59^{*}$ & $2.64^{*}$ & $5.49^{* * \#}$ \\
\hline & Neurotransmitter transporter (SIc6a4) & 1.00 & 0.84 & $0.25^{*}$ & $0.48^{* *}$ \\
\hline & Agrin (Agrn) & 1.00 & 1.32 & 1.39 & $0.48^{* \#}$ \\
\hline & Glial cell line-derived neurotrophic factor (Gdnf) & 1.00 & 1.26 & $1.32^{*}$ & $2.74^{*}$ \\
\hline & Acetylcholinesterase (Ache) & 1.00 & $1.33^{*}$ & $9.31^{*}$ & $5.14^{* \#}$ \\
\hline
\end{tabular}

Differential expression values for a subset of genes, grouped by functional categories, for WT and APP/PS1 mice. Values were measured by array analysis and were expressed as fold changes compared with control group. Fold changes were in linear scale, thus $<1.0$ means downregulated genes while $>1.0$ means upregulated. ${ }^{*} P<0.05,{ }^{* *} P<0.01$ compared with control, ${ }^{*} P<0.05$, compared with WT-BaP mice

induced activation of microglia and astroglia in the cortex and the hippocampus. Meanwhile, Western blot analysis revealed significant upregulation of gp91, iNOS, and GFAP (three widely used neuroinflammatory markers) in BaP-treated mice (Fig. 6f, g). These results together indicated that chronic $\mathrm{BaP}$ exposure led to chronic neuroinflammation.
BaP promoted neurodegeneration triggered by aged $A \beta$

We then investigated whether neuroinflammation, especially the activation of NADPH oxidase, was important for $\mathrm{BaP} / \mathrm{A} \beta$-induced neurodegeneration. After 7-day treatment, aged $\mathrm{A} \beta$ peptide $(5 \mu \mathrm{g} / \mathrm{ml} ; 1.108 \mu \mathrm{M})$, which was prepared to form a mixture of monomer, oligomers and fibrils by incubation in PBS at $37^{\circ} \mathrm{C}$ for $24 \mathrm{~h}$, caused 

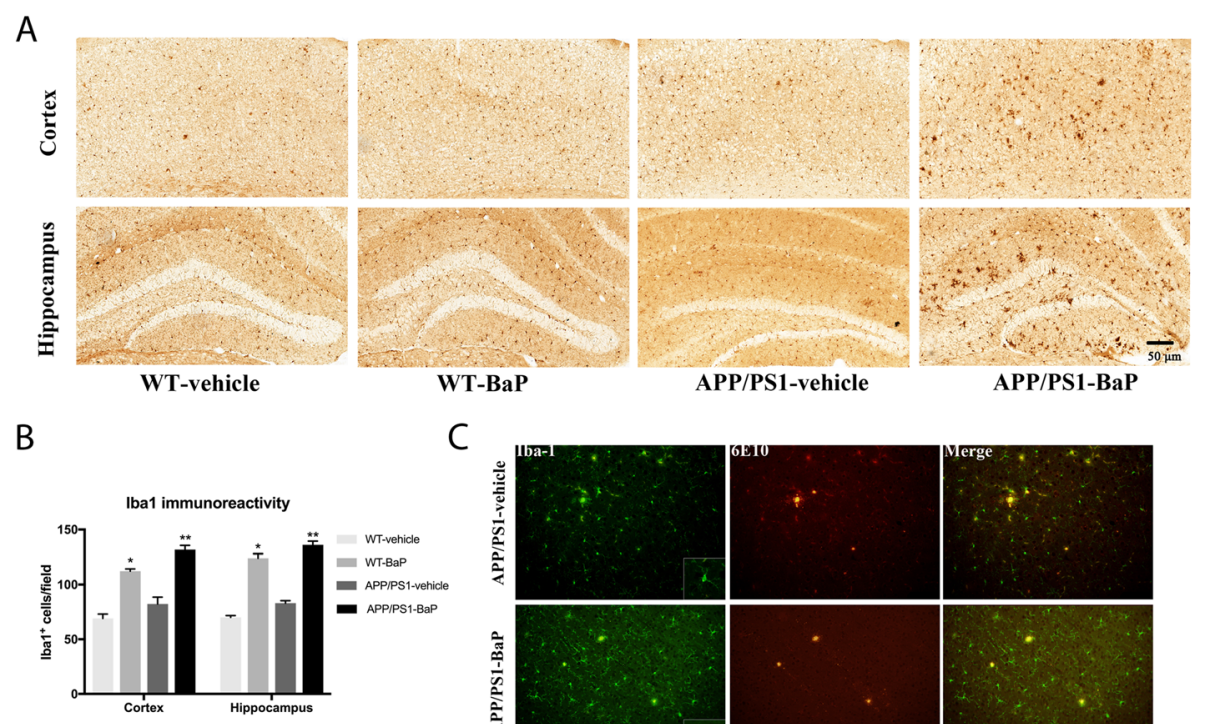

C

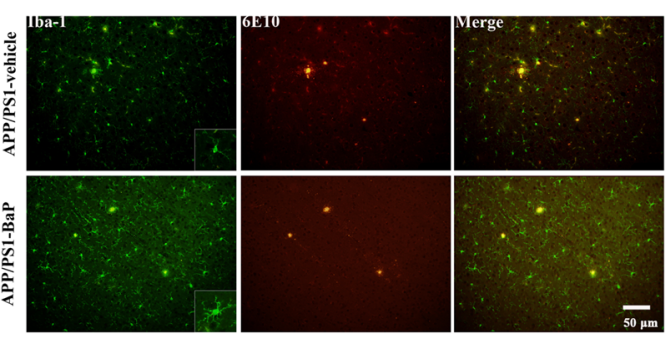

D

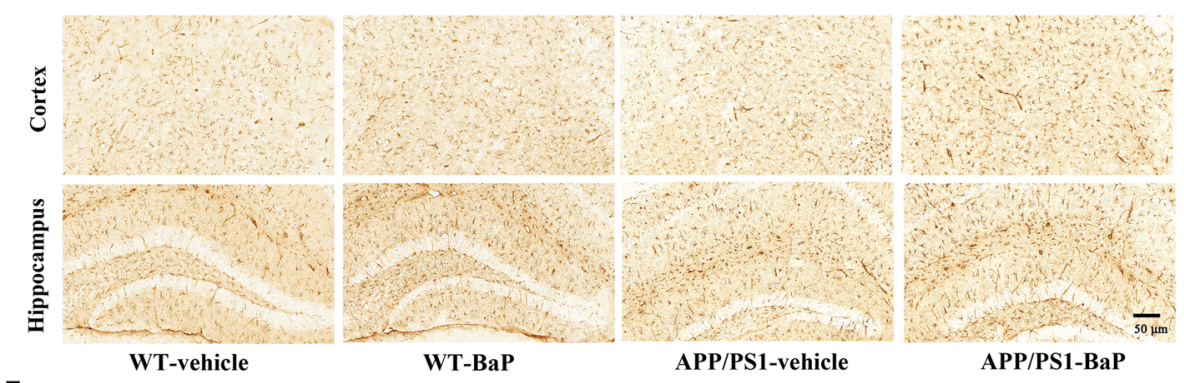

$\mathrm{E}$

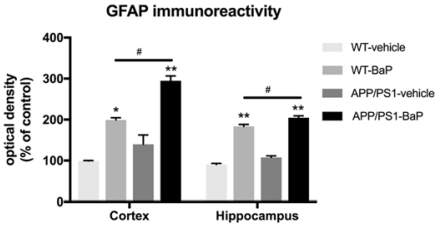

$\mathrm{F}$

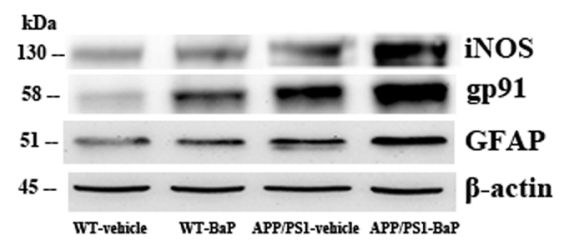

G

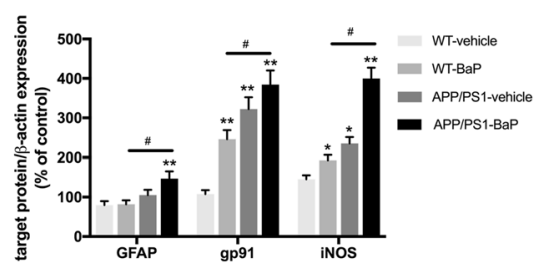

Fig. 6 Glial activation and neuroinflammation were induced after BaP exposure. a, b Microglial activation was indicated by immunostaining with Iba-1 antibody (a) and counting of Iba-1-positive cells (b) in the cortex and the hippocampus. c Confocal double-staining of microglia and $A \beta$ plaques by anti-Iba1 and anti-A $\beta$ antibodies in the hippocampus. $\mathbf{d}$ Astroglial activation was detected with anti-GFAP antibody. e The GFAP immunoreactivity was measured and expressed as a percentage of the WT-Vehicle. $\mathbf{f}$, g Levels of iNOS, gp91, and GFAP (three widely used neuroinflammatory markers) were detected by Western blot. $\beta$-Actin was used to monitor loading errors. Data are expressed as percentage of WT-Vehicle and are mean \pm SEM of 3-4 mice in each treatment group. Significance was determined by two-way ANOVA followed by LSD multiple comparisons post-hoc test. ${ }^{*} P<0.05$, ${ }^{*} P<0.01$ compared with WT-Vehicle control, ${ }^{\#} P<0.05$ compared with WT-BaP group

severe neurite injuries and shrunken bodies of THpositive neurons in primary neuron-glia cultures. Such neuronal damages became much worse after the cultures were co-treated with $\mathrm{A} \beta$ and $0.1 \mu \mathrm{M} \mathrm{BaP}$ (Fig. 7a).
Treatment with aged $A \beta$ for 7 days led to $25 \%$ loss of TH-positive neurons, while BaP promoted such neuronal loss to $49 \%$ (Fig. $7 \mathrm{~b}$ ). Thus, BaP promoted neurodegeneration induced by aged $\mathrm{A} \beta$. 


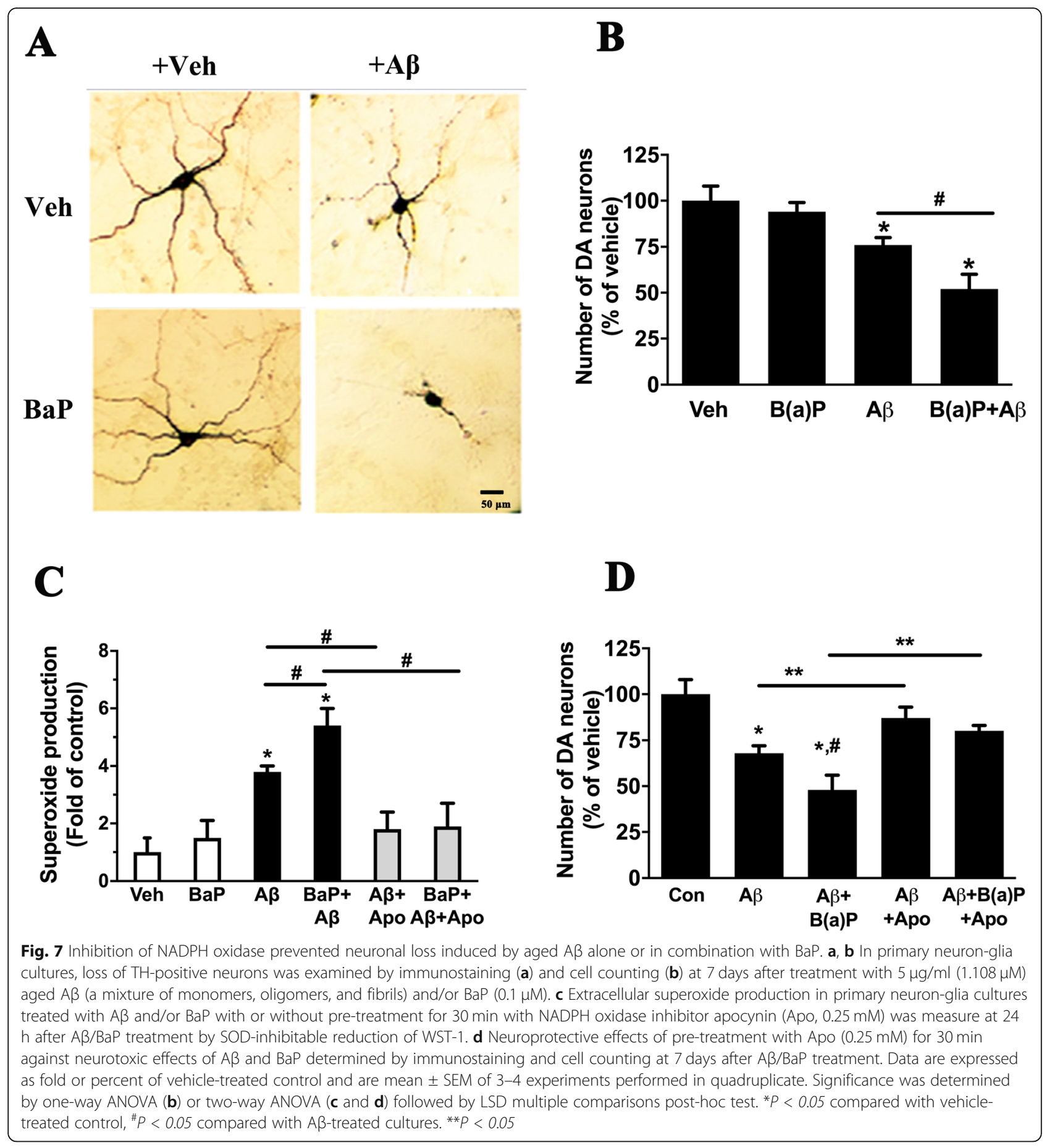

NADPH oxidase has been shown to play a pivotal role in $A \beta$-induced neurotoxicity [28-31]. Our array results showed significant upregulation of multiple subunits of $\mathrm{NADPH}$ oxidase in the cortex of BaP-exposed mice (Table 1). Western blot results also revealed upregulation of gp91 (the catalytic subunit of NADPH oxidase) in the cortex/hippocampus of BaP-exposed mice. Therefore, we investigated whether upregulated NADPH oxidase mediated $\mathrm{A} \beta / \mathrm{BaP}$-induced neurodegeneration. We first measured extracellular superoxide production in neuron-glia cultures treated with $\mathrm{A} \beta$ and/or $\mathrm{BaP}$. BaP and aged $A \beta$ showed synergistic effects on extracellular superoxide production (Fig. 7c). Moreover, pretreatment with NADPH oxidase inhibitor apocynin $(0.25 \mathrm{mM})$ for $30 \mathrm{~min}$ before treatment with aged $\mathrm{A} \beta$ alone or in combination with $\mathrm{BaP}$ only blocked 
extracellular superoxide production but also neuronal loss, which were detected at 1 day or 7 days after $\mathrm{A} \beta / \mathrm{BaP}$ treatment respectively (Fig. 7c, d). Neuroprotective effects of NADPH oxidase inhibitor on neurodegeneration induced by $\mathrm{BaP}$ and aged $\mathrm{A} \beta$ indicated that the upregulation and the activation of NADPH oxidase and resultant oxidative stress were important mediators of $\mathrm{BaP} /$ $\mathrm{A} \beta$-induced neuronal loss seen in both in vitro and in vivo studies.

\section{Discussion}

As a common and potent environmental organic pollutant, benzo(a)pyrene $(\mathrm{BaP})$ was widely investigated for its adverse health effects. Besides carcinogenicity, neurotoxicity was also emerging as the crucial adverse effects of $\mathrm{BaP}$ exposure. Previous studies have demonstrated that $\mathrm{BaP}$ exposure during early life stage affects neurodevelopmental process, such as neuritis formation or neurodifferentiation [32, 33]. However, effects of $\mathrm{BaP}$ on adult brains warrant further investigation. Studies have shown that $\mathrm{BaP}$ exposure is associated with learning and memory deficits or some AD-like pathological changes such as Tau hyperphosphorylation. Therefore, it is essential to understand whether $\mathrm{BaP}$, as an environmental risk factor of $\mathrm{AD}$, can affect the disease progression of $\mathrm{AD}$, especially neurodegeneration in the cortex and the hippocampus, the fundamental feature of $\mathrm{AD}$. In this study, we evaluated the potential role of $\mathrm{BaP}$ exposure from the initial phase of $\mathrm{AD}$ using APP/PS1 and WT mice. We found that $\mathrm{BaP}$ exposure remarkably accelerated progressive cognitive and learning decline in both genotypes. $\mathrm{BaP}$ exposure exacerbated $\mathrm{A} \beta$ burden and plaque formation as well as neuroinflammation in APP/ PS1 mice. $A \beta / \mathrm{BaP}$-induced neurodegeneration could be mainly mediated through elevated neuroinflammation and NADPH oxidase activation.

In this study, APP/PS1 transgenic mice were used to evaluate effects of $\mathrm{BaP}$ on $\mathrm{AD}$ onset and progression. APP/PS1 mice expressing a chimeric mouse/human amyloid precursor protein (Mo/HuAPP695swe) and a mutant human presenilin 1 (PS1-dE9) were often used as an early-onset AD model. The time of onset of cognitive decline in APP/PS1 mice varies. Indeed, many studies have performed behavior tests and have shown cognitive decline in APP/PS1 mice when the mice were $8-12$ month or even older [34, 35]. However, it has been reported that cognitive deficits in the Morris water maze test in the same APP/PS1 transgenic mice overexpressing human $\mathrm{APP}^{\mathrm{K} 595 \mathrm{~N}, \mathrm{M} 596 \mathrm{~L}} / \mathrm{PSEN1}{ }^{\triangle \mathrm{E} 9}$ (also called

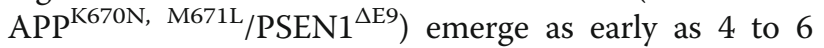
months and worsen with age [36-42]. BaP was capable to induce the neurobehavioral dysfunction in both APP/ PS1 mice and WT mice, while such decline in APP/PS1 mice was earlier and severer than that in WT mice (Figs.
2 and 3). The neuronal loss and $A \beta$ deposits in the hippocampus and the cortex were also observed in APP/ PS1 mice after 2-month BaP exposure. BaP-induced neuronal loss in 7-month APP/PS1 mice (Fig. 4) promoted cognitive decline seen in APP/PS1 mice (Figs. 2 and 3). This two-hit model of AD with both genetic predisposition (namely mutant APP/PS1 genes) and exposure to environmental pollutant $\mathrm{BaP}$ recapitulated key features of $\mathrm{AD}$ including neuronal loss. It might imply that $\mathrm{BaP}$ can fasten the pathogenesis process and disease progression in people who carry AD susceptible genes.

The behavior changes without $A \beta$ aggregation or neuronal loss/death in WT mice also indicated that $\mathrm{BaP}$ could initiate early neuronal damages and functional defects, such as neurotransmitter disturbances as well as synapse loss and dysfunction. Indeed, gene expression profiles showed significant downregulation of agrin and Slc6a4 (SERT) and remarkable upregulation of Ache in BaP-exposed mice (Table 1). All three proteins have been implicated in synaptic formation in $\mathrm{AD}$ patients or models [21-23]. Importantly, multiple studies have shown that early synaptic plasticity deficits or synapse loss, the disruption of neurotransmitters (e.g., serotonin and dopamine), and $\mathrm{A} \beta$ deposition in APP/PS1 mice correlate with cognitive decline [43-47]. In particular, synaptic dysfunction has been believed to be one of the major contributors to AD pathogenesis. Synapse loss in the hippocampus in the APP/PS1 mice occurs by 4 months of age [44]. Cognitive decline at age of 5 and 7 months in WT-BaP mice and APP/PS1-Vehicle (Fig. 2) might be partially due to synaptic defects and/or neurotransmitter imbalance but not loss/death of neurons.

Accumulating evidence has highlighted that neuroinflammation acts as an early pathophysiologic factor in the chronic progressive $A \beta$ metabolism dysfunction and neuron loss in $\mathrm{AD}[48,49]$. Our results from the gene expression profile revealed a valuable picture of inflammation and immunoregulatory process, $A \beta$ secretases, and degradation disturbance in the cortex after $\mathrm{BaP}$ exposure. Our results also revealed microglial activation and upregulation of pro-inflammatory cytokines (such as TNF $\alpha$, IL1 $\beta$, and IL6) after BaP exposure. Previous studies showed that pro-inflammatory cytokines, such as TNF $\alpha$, IL6, and IL1 $\beta$, could potentially disturb the A $\beta$ clearance and cause memory impairments [48-50]. Besides, chemokine CCL2 was also associated with A $\beta$ deposit in $\mathrm{AD}$ mice accompanied with aggravated behavior ability decline [51]. Previous studies also indicated that iNOS in AD mice was associated with plaque deposition and inflammation. The elevated NO production by upregulating iNOS in microglia could cause neurotoxicity, while the deficiency of iNOS showed protective effects in $\mathrm{AD}$ mice [52]. Consistent with these findings, in this study, both iNOS mRNA and protein were significantly 
elevated in both WT and APP/PS1 mice after BaP exposure. It suggested that iNOS could be an important inflammatory mediator in $\mathrm{BaP}$ neurotoxicity. Taken together, neuroinflammation could be initiated by $\mathrm{BaP}$ exposure and then induces the neurodegenerative process.

Our in vivo results showed that 2-month $\mathrm{BaP}$ exposure led to activation of microglia and astrocytes (Fig. 6 and Table 1). Lactational exposure to BaP induces astroglial activation and anxiety-like behavior in mice [53]. Subchronic oral administration of BaP $(2 \mathrm{mg} / \mathrm{kg} /$ day for 28 days) causes astroglial reaction and motor/cognitive impairments in rats [54]. A previous study has shown that treatment of BV2 (mouse microglial cell line) with $\mathrm{BaP}$ $(10 \mu \mathrm{M})$ triggered inflammatory responses, such as upregulation of iNOS and cyclooxygenase-2 (COX-2) as well as production of multiple pro-inflammatory factors including nitric oxide (NO), reactive oxygen species (ROS), IL-1 $\beta$, and IL-6 [55]. Benzo[a]pyrene diol epoxide, the major metabolite of $\mathrm{BaP}$, has been shown to upregulate COX-2 expression in rat astroglia [56]. Multiple lines of evidence implicated participation of upregulation and activation of NADPH oxidase in BaP-induced or BaP-amplified neuronal damages (Table 1, Fig. $6 \mathrm{f}$ and Fig. 7c, d). NADPH oxidase is mainly expressed in microglia and is the major source of extracellular superoxide during inflammation [29, 31, 57]. These findings together implied that microglial activation may be important for effects of BaP observed in this study with involvement of astroglia and/or neurons.

Previous studies including ours have shown that NADPH oxidase plays a pivotal role in A $\beta$-induced neurotoxicity [29-31, 58]. NADPH oxidase is mainly expressed in microglia [31]. Upregulated and/or overactivated NADPH oxidase is a major source of oxidative stress and oxidative neuronal damages during neuroinflammation and has been implicated as a therapeutic target for neurodegenerative diseases including $\mathrm{AD}$ [58]. In neuron-glia cultures, while aged $A \beta$ (a mixture of monomers, oligomers, and fibrils) induced neuronal death, $A \beta$ and "non-toxic" dose of $\mathrm{BaP}$ together caused synergistic neurodegeneration (Fig. 7). Mechanistically, $\mathrm{BaP}$ and aged $A \beta$ synergistically induced extracellular superoxide production (Fig. 7c). While gene expression profiling showed significant increases in subunits of NADPH oxidase including gp91, p47, p67, and p40 (Table 1), Western blot results also revealed upregulation of gp91 protein (the catalytic subunit of NADPH oxidase) in the cortex of WT mice with BaP exposure and APP/PS1 mice with or without $\mathrm{BaP}$ exposure (Fig. 6f). More importantly, pre-treatment with NADPH oxidase inhibitor apocynin $(0.25 \mathrm{mM})$ for $30 \mathrm{~min}$ protected cultured neurons against neurotoxicity of $A \beta$ alone or in combination with BaP (Fig. 7d). Therefore, activation of NADPH oxidase and resultant oxidative stress were critical mechanisms for neuronal death induced by $A \beta$ alone or combined with BaP. NADPH oxidase could be a crucial mediator for BaP-induced pathogenic process of $\mathrm{AD}$.

\section{Conclusions}

In summary, this study showed that $\mathrm{BaP}$ exposure induced and accelerated the progression of $\mathrm{AD}$, in which neuroinflammation could be an early key event. Findings from this study suggested that $\mathrm{BaP}$ was an environmental risk factor for AD neurodegenerative diseases.

\section{Supplementary information}

Supplementary information accompanies this paper at https://doi.org/10. 1186/s12974-020-01925-y.

Additional file 1: Supplemental Table S1. Mouse Alzheimer's Disease RT2 Profiler PCR Array.

\section{Abbreviations \\ BaP: Benzo(a)pyrene; AD: Alzheimer's disease; APP/PS1: APPswe/PS1dE9; WT: Wildtype; A $\beta$ : Beta-amyloid; PAHs: Polycyclic aromatic hydrocarbons; Iba1: Ionized calcium-binding adapter molecule 1; GFAP: Glial fibrillary acidic protein; NADPH: Nicotinamide adenine dinucleotide phosphate oxidase; BDNF: Brain-derived neurotrophic factor; GDNF: Glial cell line-derived neuro- trophic factor}

\section{Acknowledgements}

We thank Professor Yan Yang of Chinese Academy of Science for assistance in brain section collection.

\section{Authors' contributions}

$\mathrm{DL}, \mathrm{HZ}$, and HMG designed the study. DL, YJZ, YZQ, YG, DZT, and YXW conducted the experiments. $\mathrm{DL}, \mathrm{HZ}$, and $\mathrm{HMG}$ analyzed the data and wrote the manuscript. All authors have read and approved the final version of the manuscript.

\section{Funding}

This study was supported by grants from National Natural Science Foundation of China [grant No. 21577004] and Beijing Municipal Natural Science Foundation [grant No. 7162104].

\section{Availability of data and materials}

The datasets used and/or analyzed during the current study are available from the corresponding author on reasonable request.

Ethics approval and consent to participate

All the use of animals were performed in strict accordance with the guidelines of the Animal Care and Committee of Nanjing University.

\section{Consent for publication}

Not applicable.

\section{Competing interests}

The authors declare that they have no known competing financial interests or personal relationships that could have appeared to influence the work reported in this paper.

\section{Author details}

${ }^{1}$ Department of Occupational and Environmental Health Sciences, Peking University, Beijing 100191, China. ${ }^{2}$ Population Health Sciences, German Centre for Neurodegenerative Diseases (DZNE), Bonn, Germany. ${ }^{3} \mathrm{MOE}$ Key Laboratory of Model Animal for Disease Study, Model Animal Research Center, Institute for Brain Sciences, Nanjing University, 12 Xuefu Road, Nanjing 210061, Jiangsu Province, China. 
Received: 29 September 2019 Accepted: 13 August 2020 Published online: 31 August 2020

\section{References}

1. Mayeux R, Stern Y. Epidemiology of Alzheimer disease. Cold Spring Harb Perspect Med. 2012;2:137.

2. Scheltens P, Blennow K, Breteler MM, de Strooper B, Frisoni GB, Salloway S, et al. Alzheimer's disease. Lancet. 2016;388:505-17.

3. Chin-Chan M, Navarro-Yepes J, Quintanilla-Vega B. Environmental pollutants as risk factors for neurodegenerative disorders: Alzheimer and Parkinson diseases. Front Cell Neurosci. 2015:9:124

4. Wallin C, Sholts SB, Osterlund N, Luo J, Jarvet J, Roos PM, et al. Alzheimer's disease and cigarette smoke components: effects of nicotine, PAHs, and $\mathrm{cd}(\mathrm{II}), \mathrm{Cr}(\mathrm{III}), \mathrm{Pb}(\mathrm{II}), \mathrm{Pb}(\mathrm{IV})$ ions on amyloid-beta peptide aggregation. Sci Rep. 2017:7:14423.

5. Calderon-Garciduenas L, Reed W, Maronpot RR, Henriquez-Roldan C, Delgado-Chavez R, Calderon-Garciduenas A, et al. Brain inflammation and Alzheimer's-like pathology in individuals exposed to severe air pollution. Toxicol Pathol. 2004:32:650-8

6. Courter LA, Pereira C, Baird WM. Diesel exhaust influences carcinogenic PAH-induced genotoxicity and gene expression in human breast epithelial cells in culture. Mutat Res. 2007:625:72-82.

7. Riemschneider S, Kohlschmidt J, Fueldner C, Esser C, Hauschildt S, Lehmann J. Aryl hydrocarbon receptor activation by benzo(a)pyrene inhibits proliferation of myeloid precursor cells and alters the differentiation state as well as the functional phenotype of murine bone marrow-derived macrophages. Toxicol Lett. 2018;296:106-13.

8. Rouet $P$, Alexandrov K, Markovits P, Frayssinet C, Dansette PM. Metabolism of benzo[a]pyrene by brain microsomes of fetal and adult rats and mice. Induction by 5,6 benzoflavone, comparison with liver and lung microsomal activities. Carcinogenesis. 1981;2:919-26.

9. Niu Q, Zhang H, Li X, Li M. Benzo[a]pyrene-induced neurobehavioral function and neurotransmitter alterations in coke oven workers. Occup Environ Med. 2010;67:444-8.

10. Qiu C, Peng B, Cheng S, Xia Y, Tu B. The effect of occupational exposure to benzo[a]pyrene on neurobehavioral function in coke oven workers. Am J Ind Med. 2013;56:347-55.

11. Zhang W, Tian F, Zheng J, Li S, Qiang M. Chronic administration of benzo(a)pyrene induces memory impairment and anxiety-like behavior and increases of NR2B DNA methylation. PLoS One. 2016;11:e0149574.

12. Gao D, Wang C, Xi Z, Zhou Y, Wang Y, Zuo Z. Early-life benzo[a]pyrene exposure causes neurodegenerative syndromes in adult zebrafish (Danio rerio) and the mechanism involved. Toxicol Sci. 2017:157:74-84

13. Cheng SQ, Xia YY, He JL, Liu XQ, Chen XM, Ding YB, et al. Neurotoxic effect of subacute benzo(a)pyrene exposure on gene and protein expression in Sprague-Dawley rats. Environ Toxicol Pharmacol. 2013;36:648-58.

14. Nie J, Duan L, Yan Z, Niu Q. Tau hyperphosphorylation is associated with spatial learning and memory after exposure to benzo[a]pyrene in SD rats. Neurotox Res. 2013;24:461-71.

15. Garcia-Alloza M, Robbins EM, Zhang-Nunes SX, Purcell SM, Betensky RA, Raju $S$, et al. Characterization of amyloid deposition in the APPswe/PS1dE9 mouse model of Alzheimer disease. Neurobiol Dis. 2006;24:516-24.

16. Vorhees CV, Williams MT. Morris water maze: procedures for assessing spatial and related forms of learning and memory. Nat Protoc. 2006;1:848-58.

17. Gao HM, Jiang J, Wilson B, Zhang W, Hong JS, Liu B. Microglial activationmediated delayed and progressive degeneration of rat nigral dopaminergic neurons: relevance to Parkinson's disease. J Neurochem. 2002;81:1285-97.

18. Gao HM, Zhou H, Zhang F, Wilson BC, Kam W, Hong JS. HMGB1 acts on microglia Mac1 to mediate chronic neuroinflammation that drives progressive neurodegeneration. J Neurosci. 2011;31:1081-92.

19. Stine WB Jr, Dahlgren KN, Krafft GA, LaDu MJ. In vitro characterization of conditions for amyloid-beta peptide oligomerization and fibrillogenesis. J Biol Chem. 2003:278:11612-22.

20. Zhou H, Zhang F, Chen SH, Zhang D, Wilson B, Hong JS, et al. Rotenone activates phagocyte NADPH oxidase by binding to its membrane subunit gp91phox. Free Radic Biol Med. 2012;52:303-13.

21. Donahue JE, Berzin TM, Rafii MS, Glass DJ, Yancopoulos GD, Fallon JR, et al. Agrin in Alzheimer's disease: altered solubility and abnormal distribution within microvasculature and brain parenchyma. Proc Natl Acad Sci U S A. 1999;96:6468-72.
22. Ksiazek I, Burkhardt C, Lin S, Seddik R, Maj M, Bezakova G, et al. Synapse loss in cortex of agrin-deficient mice after genetic rescue of perinatal death. J Neurosci. 2007;27:7183-95.

23. Misgeld T, Kummer TT, Lichtman JW, Sanes JR. Agrin promotes synaptic differentiation by counteracting an inhibitory effect of neurotransmitter. Proc Natl Acad Sci U S A. 2005;102:11088-93.

24. Smith GS, Barrett FS, Joo JH, Nassery N, Savonenko A, Sodums DJ, et al. Molecular imaging of serotonin degeneration in mild cognitive impairment. Neurobiol Dis. 2017;105:33-41.

25. Thomas AJ, Hendriksen M, Piggott M, Ferrier IN, Perry E, Ince P, et al. A study of the serotonin transporter in the prefrontal cortex in late-life depression and Alzheimer's disease with and without depression. Neuropathol Appl Neurobiol. 2006:32:296-303.

26. Garcia-Ayllon MS, Riba-Llena I, Serra-Basante C, Alom J, Boopathy R, SaezValero J. Altered levels of acetylcholinesterase in Alzheimer plasma. PLoS One. 2010;5:e8701.

27. Garcia-Ayllon MS, Small DH, Avila J, Saez-Valero J. Revisiting the role of acetylcholinesterase in Alzheimer's disease: cross-talk with P-tau and betaamyloid. Front Mol Neurosci. 2011;4:22.

28. Abramov AY, Duchen MR. The role of an astrocytic NADPH oxidase in the neurotoxicity of amyloid beta peptides. Philos Trans R Soc Lond Ser B Biol Sci. 2005;360:2309-14.

29. Wilkinson BL, Landreth GE. The microglial NADPH oxidase complex as a source of oxidative stress in Alzheimer's disease. J Neuroinflammation. 2006;3:30.

30. Qin L, Liu Y, Cooper C, Liu B, Wilson B, Hong JS. Microglia enhance betaamyloid peptide-induced toxicity in cortical and mesencephalic neurons by producing reactive oxygen species. J Neurochem. 2002;83:973-83.

31. Zhang D, Hu X, Qian L, Chen SH, Zhou H, Wilson B, et al. Microglial MAC1 receptor and $\mathrm{PI} 3 \mathrm{~K}$ are essential in mediating beta-amyloid peptide-induced microglial activation and subsequent neurotoxicity. J Neuroinflammation. 2011:8:3.

32. Edwards SC, Jedrychowski W, Butscher M, Camann D, Kieltyka A, Mroz E, et al. Prenatal exposure to airborne polycyclic aromatic hydrocarbons and children's intelligence at 5 years of age in a prospective cohort study in Poland. Environ Health Perspect. 2010;118:1326-31.

33. Patel B, Das SK, Das S, Das L, Patri M. Neonatal exposure to benzo[a]pyrene induces oxidative stress causing altered hippocampal cytomorphometry and behavior during early adolescence period of male Wistar rats. Int J Dev Neurosci. 2016;50:7-15.

34. Lalonde R, Kim HD, Maxwell JA, Fukuchi K. Exploratory activity and spatial learning in 12-month-old APP(695)SWE/Co+PS1/DeltaE9 mice with amyloid plaques. Neurosci Lett. 2005;390:87-92.

35. Volianskis A, Kostner R, Molgaard M, Hass S, Jensen MS. Episodic memory deficits are not related to altered glutamatergic synaptic transmission and plasticity in the CA1 hippocampus of the APPswe/PS1deltaE9-deleted transgenic mice model of ss-amyloidosis. Neurobiol Aging. 2010;31:1173-87.

36. Barbero-Camps E, Fernandez A, Martinez L, Fernandez-Checa JC, Colell A. APP/PS1 mice overexpressing SREBP-2 exhibit combined Abeta accumulation and tau pathology underlying Alzheimer's disease. Hum Mol Genet. 2013;22:3460-76.

37. Izco M, Martinez P, Corrales A, Fandos N, Garcia S, Insua D, et al. Changes in the brain and plasma Abeta peptide levels with age and its relationship with cognitive impairment in the APPswe/PS1dE9 mouse model of Alzheimer's disease. Neuroscience. 2014;263:269-79.

38. Minkeviciene $\mathrm{R}$, Ihalainen J, Malm T, Matilainen O, Keksa-Goldsteine V, Goldsteins $\mathrm{G}$, et al. Age-related decrease in stimulated glutamate release and vesicular glutamate transporters in APP/PS1 transgenic and wild-type mice. J Neurochem. 2008;105:584-94.

39. Na JY, Song K, Lee JW, Kim S, Kwon J. 6-Shogaol has anti-amyloidogenic activity and ameliorates Alzheimer's disease via CysLT1R-mediated inhibition of cathepsin B. Biochem Biophys Res Commun. 2016:477:96-102.

40. Verheijen BM, Stevens JAA, RJG G, van 't Hekke CD, van den DLA H, Hermes $D$, et al. Paradoxical effects of mutant ubiquitin on Abeta plaque formation in an Alzheimer mouse model. Neurobiol Aging. 2018;72:62-71.

41. Yang W, Zhou K, Zhou Y, An Y, Hu T, Lu J, et al. Naringin dihydrochalcone ameliorates cognitive deficits and neuropathology in APP/PS1 transgenic mice. Front Aging Neurosci. 2018;10:169.

42. Zhang P, Kishimoto Y, Grammatikakis I, Gottimukkala K, Cutler RG, Zhang S, et al. Senolytic therapy alleviates Abeta-associated oligodendrocyte progenitor cell senescence and cognitive deficits in an Alzheimer's disease model. Nat Neurosci. 2019;22:719-28. 
43. Bruce-Keller AJ, Gupta S, Knight AG, Beckett TL, McMullen JM, Davis PR, et al. Cognitive impairment in humanized APPXPS1 mice is linked to Abeta(1-42) and NOX activation. Neurobiol Dis. 2011;44:317-26.

44. Hong S, Beja-Glasser VF, Nfonoyim BM, Frouin A, Li S, Ramakrishnan S, et al. Complement and microglia mediate early synapse loss in Alzheimer mouse models. Science. 2016;352:712-6.

45. Terry RD, Masliah E, Salmon DP, Butters N, DeTeresa R, Hill R, et al. Physical basis of cognitive alterations in Alzheimer's disease: synapse loss is the major correlate of cognitive impairment. Ann Neurol. 1991;30:572-80.

46. Viana da Silva S, Haberl MG, Zhang P, Bethge P, Lemos C, Goncalves N, et al. Early synaptic deficits in the APP/PS1 mouse model of Alzheimer's disease involve neuronal adenosine A2A receptors. Nat Commun. 2016;7: 11915.

47. Wei BB, Liu MY, Chen ZX, Wei MJ. Schisandrin ameliorates cognitive impairment and attenuates Abeta deposition in APP/PS1 transgenic mice: involvement of adjusting neurotransmitters and their metabolite changes in the brain. Acta Pharmacol Sin. 2018:39:616-25.

48. Heneka MT, Carson MJ, El Khoury J, Landreth GE, Brosseron F, Feinstein DL, et al. Neuroinflammation in Alzheimer's disease. Lancet Neurol. 2015;14:388-405.

49. Heppner FL, Ransohoff RM, Becher B. Immune attack: the role of inflammation in Alzheimer disease. Nat Rev Neurosci. 2015;16:358-72.

50. Zhang YY, Fan YC, Wang M, Wang D, Li XH. Atorvastatin attenuates the production of IL-1 beta, IL-6, and TNF-alpha in the hippocampus of an amyloid beta1-42-induced rat model of Alzheimer's disease. Clin Interv Aging. 2013:8:103-10.

51. Kiyota T, Yamamoto M, Schroder B, Jacobsen MT, Swan RJ, Lambert MP, et al. AAV1/2-mediated CNS gene delivery of dominant-negative CCL2 mutant suppresses gliosis, beta-amyloidosis, and learning impairment of APP/PS1 mice. Mol Ther. 2009;17:803-9.

52. Nathan C, Calingasan N, Nezezon J, Ding A, Lucia MS, La Perle K, et al. Protection from Alzheimer's-like disease in the mouse by genetic ablation of inducible nitric oxide synthase. J Exp Med. 2005;202:1163-9.

53. Yang C, Han P, Ruan F, Zhou T, Luo B, Qiu Y, et al. Lactational exposure to environmentally relevant benzo(a)pyrene causes astrocytic activation and anxiety-like behavior in male mice. Chemosphere. 2019;221:67-74.

54. Maciel ES, Biasibetti R, Costa AP, Lunardi P, Schunck RV, Becker GC, et al. Subchronic oral administration of benzo[a]pyrene impairs motor and cognitive behavior and modulates S100B levels and MAPKs in rats. Neurochem Res. 2014:39:731-40.

55. Bao Y, Chen Q, Xie Y, Tao Z, Jin K, Chen S, et al. Ferulic acid attenuates oxidative DNA damage and inflammatory responses in microglia induced by benzo(a)pyrene. Int Immunopharmacol. 2019;77:105980.

56. Weng MW, Hsiao YM, Chen CJ, Wang JP, Chen WC, Ko JL. Benzo[a]pyrene diol epoxide up-regulates COX-2 expression through NF-kappaB in rat astrocytes. Toxicol Lett. 2004;151:345-55.

57. Gao HM, Hong JS, Zhang W, Liu B. Distinct role for microglia in rotenoneinduced degeneration of dopaminergic neurons. J Neurosci. 2002;22:78290.

58. Gao HM, Zhou H, Hong JS. NADPH oxidases: novel therapeutic targets for neurodegenerative diseases. Trends Pharmacol Sci. 2012;33:295-303.

\section{Publisher's Note}

Springer Nature remains neutral with regard to jurisdictional claims in published maps and institutional affiliations.

\section{Ready to submit your research? Choose BMC and benefit from:}

- fast, convenient online submission

- thorough peer review by experienced researchers in your field

- rapid publication on acceptance

- support for research data, including large and complex data types

- gold Open Access which fosters wider collaboration and increased citations

- maximum visibility for your research: over $100 \mathrm{M}$ website views per year

At $\mathrm{BMC}$, research is always in progress.

Learn more biomedcentral.com/submissions 